\author{
Ewa Kocój \\ (Jagiellonian University in Kraków)
}

\title{
Artifacts of the Past as Traces of Memory. The Aromanian Cultural Heritage in the Balkans
}

\author{
Artefakty przeszłości jako ślady pamięci. Dziedzictwo \\ kulturowe Aromanów na Bałkanach
}

I wish I could become a chronicler of places which never existed on the map, and events of which history never took any notice ${ }^{1}$.

\section{STRESZCZENIE}

Celem tego artykułu jest odpowiedź na kilka pytań: (1) jakie ślady materialnego dziedzictwa kulturowego Aromanów (Wlachów) odnajdujemy na terenach dzisiejszej Albanii, Grecji i Republiki Macedonii; (2) co mówią one o społeczności lokalnej, jej historii i znaczeniu w kulturze europejskiej; (3) czy istnieje współcześnie aromańska pamięć zbiorowa dotycząca miejsc, w których zachowały się ślady tego dziedzictwa? W tekście dokonano opisu regionów, które zamieszkiwali Aromanie, zaprezentowano wstępne kryteria podziału ich dziedzictwa kulturowego na grupy, przypisując im wybrane przykłady zabytków, a także wskazano, jakie wybrane znaczenia i sensy związane z kulturą aromańską odkrywamy, traktując owe zabytki jako tekst kultury.

$\mathrm{W}$ artykule wykorzystano jakościowe metody badań terenowych, w tym wywiady i obserwacje związane ze śladami tego dziedzictwa w wybranych miejscowościach Grecji, Albanii i Republiki Macedonii, wraz z wykonaniem dokumentacji fotograficznej. Badaniu poddano także źródła zastane (historyczne i etnograficzne) oraz zasoby dostępne w Internecie - przeanalizowano narracje dotyczące odpowiednich zabytków w źródłach etnograficznych (dawnych i współczesnych wspomnieniach Aromanów) znajdujące się w nowych mediach, w tym na blogach i portalach internetowych. W analizie posłużono się paradygmatem historyczno-porównawczym i interpretatywnym, co pozwalało na badanie ukrytych znaczeń i kodów kulturowych związanych z dziedzictwem aromańskim.

Badania pokazały, że na terenie Bałkanów zachowały się liczne artefakty dziedzictwa kulturowego Aromanów, z którymi związane są rozmaite sensy i znaczenia (m.in. organizacja przestrzeni, przestrzenie realne i mityczne, wielokulturowość i konflikt).

\footnotetext{
${ }^{1}$ J. Maurer, The Doubles, transl. A. Topornicka, Kielce 2002, p. 180.
} 
Słowa kluczowe: Aromanie/Wołosi, Bałkany, dziedzictwo kulturowe, pamięć kulturowa, miejsca symboliczne, cerkwie i monastyry, ikony, budownictwo, wielokulturowość i konflikt

\section{INTRODUCTION}

Who were, or rather who are Aromanians? Where do they come from? What is their history and what were the directions of their migration? How long did they live in their original areas and then in the areas they subsequently inhabited? Although these questions have been asked for years, to this day no researcher has managed to provide exhaustive answers. What is more, the existing scientific findings concerning the Aromanian issue, which largely reflect the national aspirations of different Balkan peoples, are already mostly outdated and in many aspects simply untrue. Blank pages in historical and ethnographic sources about Aromanians, their difficult history, and the common practice of erasing and/or appropriating their heritage by majority communities, all indicate that the phenomenon of this vanishing ethnos requires appropriately impartial and independent research that would lead to reliable answers to the above-mentioned fundamental questions. These questions concern issues, which are extremely topical in today's united Europe - Europe that is seeking its common heritage and rediscovering traditions that have almost sunk into oblivion.

The domains which have not yet been thoroughly explored by researchers include the tangible and intangible cultural heritage of the Aromanian minority inhabiting European territories. Although information about sites being part of this heritage has been emerging in European studies since the beginning of the $20^{\text {th }}$ century, we still lack a general, comparative and interdisciplinary perspective on the issue. In the meantime, we should first ask ourselves the following question: has the formerly strong Aromanian ethnos - once scattered throughout many European countries by history, divided into distinct social groups, performing a variety of professions, and undergoing the varying degrees of integration and assimilation with the majority communities with which it lived - left any artifacts that could now be regarded as its cultural heritage? If so, what kind of traces of the Aromanian cultural heritage can be found in Europe of today (types, dating, function, symbolism) and what do they tell us about the local community and its history, and significance in European culture? Is there today any Aromanian collective memory of these artifacts? Are they a factor which contributes to integration in any way? Can we use them to draw 
conclusions about the specific features of Aromanian culture and its tangible and intangible heritage, and what conclusions could there be?

Searching for the traces of the Aromanian cultural heritage in contemporary Europe is not an easy task. It is worth noting that at the current stage of research, it is impossible to provide a comprehensive description of the problem of the said heritage, because there are no exhaustive historical and ethnographic sources that could fill the numerous gaps in this research area. What makes it even more challenging is the fact that the topic has to be explored contextually, i.e. we need to factor in different perspectives, including, first and foremost, the point of view of Aromanians themselves - those who admit to belong to this minority today as well as those who have lost the memory of their roots - but also consider the way the Aromanian heritage functions in the memory of aliens, including scientific outlooks on the problem. Furthermore, it is necessary to discover regularities that govern the Vlach heritage, taking into account monuments which have survived to this day as well as monuments which only live in our memory. As I have already indicated, it will require broad interdisciplinary studies ${ }^{2}$.

My research work is guided by the conviction that the tangible evidence of the Aromanian cultural heritage constitutes the text of culture which can be read on many levels. What is particularly important to me is exploring the discourses associated with this heritage, which are found among Aromanians themselves and also among the majority communities inhabiting the areas where the relevant monuments are located. We also touch upon the question of the real and imagined identity, as well as of the relationship between the tangible heritage site and its associated intangible sphere: beliefs, customs, rituals, religious cult, ancient professions, mythology, and specific local stories that comprise the so-called cultural

${ }^{2}$ The difficulties of historical and cultural studies in the Balkans have been written about by i.e.: N. S. Balamaci, Can the Vlachs Write Their Own History?, "Journal of Hellenic Diaspora" 1991, 17, January, pp. 9-36, http://pl.scribd.com/doc/46327940/Can-the-VlachsWrite-Their-Own-History\#scribd [accessed on: 31 October 2015]; N. S. Balamaci, The Vlachs in Albania. A Travel Memoir and Oral History, http://www.farsarotul.org/nl14_1.htm [accessed on: 31 October 2015]; T. Czekalski, Perypetie historyka - o specyfice badań nad przeszłościa w krajach bałkańskich, in: Tematy trudne. Sytuacje badawcze, ed. I. B. Kuźma, Łódź 2013, pp. 143-154; T. Czekalski, Zarys dziejów chrześcijaństwa albańskiego w latach 1912-1993, Kraków 1996; E. Kocój, Heritage Without Heirs? Tangible and Religious Cultural Heritage of the Vlachs Minority in Europe in the Context of Interdisciplinary Research Project (Contribution to the Subject), "Balcanica Posnaniensia. Acta et studia. Ius Valachicum I" 2015, 22, 1, pp. 137-147; E. Kocój, Dziedzictwo bez dziedzica? Materialne i religijne dziedzictwo kulturowe mniejszości pochodzenia wołoskiego w Europie w kontekście projektu interdyscyplinarnych badań (przyczynek do tematu - I), „Zarządzanie w Kulturze” 2015, 2, pp. 137-150. 
memory. I am aware that researching the cultural heritage of Aromanians is all the more difficult due to the fact that their culture was not literate for a long time (although it has preserved old tangible artifacts) and was marked by a significant predominance of oral transmission, resulting in a scarce number of surviving written sources from the past centuries. Therefore, my attempt is to reconstruct that culture based on the fragments of historical and ethnographic records, and complement it with the available recollections of Aromanians - the recollections which are part of their collective memory. I repeat: I consider a cultural heritage site to be the text of culture and also the starting point for reading Aromanian culture, which exists primarily in the world of oral history. I realize that similar attempts doom the description of the researched cultural reality to a certain kind of subjectivity and, moreover, that the elements researchers regard as part of the heritage they study are often arbitrary and have no confirmation among the community involved. Moreover, that community itself is not always interested in preserving the memory of their own tradition. All this, however, is typical of reconstructing the cultural heritage, the dominant feature of which is orality and lack of written sources. On the other hand, I believe my method of presenting the problem seems to be the most appropriate for the culture I am researching; what is more, it reveals bias in the ideological and nationalist interpretations of this culture - even the ones that claim the right to be scientific.

Originally, I intended to examine the Aromanian heritage based on the division of Aromanians into groups which was previously adopted by some researchers (including Farsherots, Moscopolitans, Muzachiars and Pindians). However, while conducting my field studies, it dawned on me that the existing nomenclature related to this ethnic group was coined on the rising tide of nascent nationalism and regionalism by researchers of the $19^{\text {th }}$ and $20^{\text {th }}$ centuries, and then copied in numerous scientific publications, which means that, as such, it has nothing to do with today's reality - and perhaps was already outdated back then. Aromanian culture turns out to be much richer than expected. It requires the researcher to thoroughly verify the old names and add a number of new ones. When taking on this task, on the one hand, one should keep in mind the archaic basis of Aromanian onomastics, which connects first names and also family names, tribe names, etc. with profession and place of residence; on the other hand, one should remember about the complexity of Aromanian identity, which usually has several roots, especially today. For these reasons, in order to study the issue, I have adopted the method of "small steps", which will enable me to gradually expand my comparative study and scientific reflection to include increasingly broad areas of Aromanian culture. I will 
be able to find similarities and differences between various areas of the cultural heritage in question and thus develop a future strategy for the revitalization and management of this heritage. It will be also interesting to compare the Aromanian cultural heritage with the preserved monuments of Vlach culture located in other countries.

To achieve my goal, I have applied a multifaceted research methodology. I have analyzed the available historical and ethnographic sources on Aromanians, and also the reports prepared by scholars and nongovernmental organizations working to promote the rights of minorities and revitalize their cultural heritage. Furthermore, in 2013-2015, I used interviews and participant observation to initiate field research on the traces of the Aromanian heritage in selected Aromanian villages in Greece, Albania, and Republic of Macedonia. This research is in the initial phase - I am continuing it in the Balkans and in different parts of the Vlach oikumene (Poland, Slovakia, Czech Republic, Ukraine and Romania). I have also made use of Internet research. Namely, I have scrutinized the narratives about the relevant sites, which are available in new media, including blogs and websites. I treat such accounts as evidence of what is preserved in the collective memory. In my analysis, I used the comparative historical paradigm and the interpretative paradigm, both of which made it possible to study the hidden cultural meanings and codes related to the Aromanian cultural heritage.

\section{THE IMAGINED GEOGRAPHY OF THE REGION}

The Aromanians, also often referred to as the Vlachs, describe themselves as: Armânji or Rrâmânji. Researchers count them among the so-called paleo-Roman peoples, who are probably the descendants of ancient nations inhabiting the territories of Epirus, Illyria and Thrace - the areas under the influence of Greek and Roman culture. Their identity was also impacted by numerous ethnic groups flocking into these areas during the migration period and conquests, especially by Slavs and Turks. This melting pot gave rise to a number of culturally and linguistically unique ethnic groups, including Aromanians - the Romance-speaking population, for which the days of antiquity (especially ancient Rome) are a reference point when it comes to their origin, and the Hellenic culture of their times is a yardstick of their education, progress of their civilization, and thereby prestige.

I will start my search for the traces of cultural heritage in the "heart" of the Aromanian territories, i.e. what are now southern and central Albania, northern Greece, and south-western part of the Republic of Mace- 
donia. In contemporary Albania, the Aromanian areas include the region of Northern Epirus along the Greek border in the Korçë County (including the vicinity of Voskopojë and Korçë, and the surrounding villages, from where, according to some $19^{\text {th }}$ century scholars, the name Moscopolitans stems) and the Gjirokastër County (the area near the village of Frashër, for which scholars used to coin the name Farsherots), and the land of Muzachia (Albanian: Myzeqe) located in central-west Albania between the Shkumbin and Seman rivers, up to the mouth of the river Vjosë/Aoös (as reported by researchers, this land was to give rise to the name of Aromanians-Muzachiars). The land includes part of the counties of Fier and Lushnjë, as well as a small part of the Vlore and Berat Counties.

In Greece, the Aromanian areas include the region of Epirus (with the Pindos Mountains extending from near the city of Arta in the south and up to the borders of Albania in the north), the region of Thessaly, and the areas of western and central Macedonia extending east from Epirus and constituting a natural destination of past and present transhumance migrations to winter pastures ${ }^{3}$.

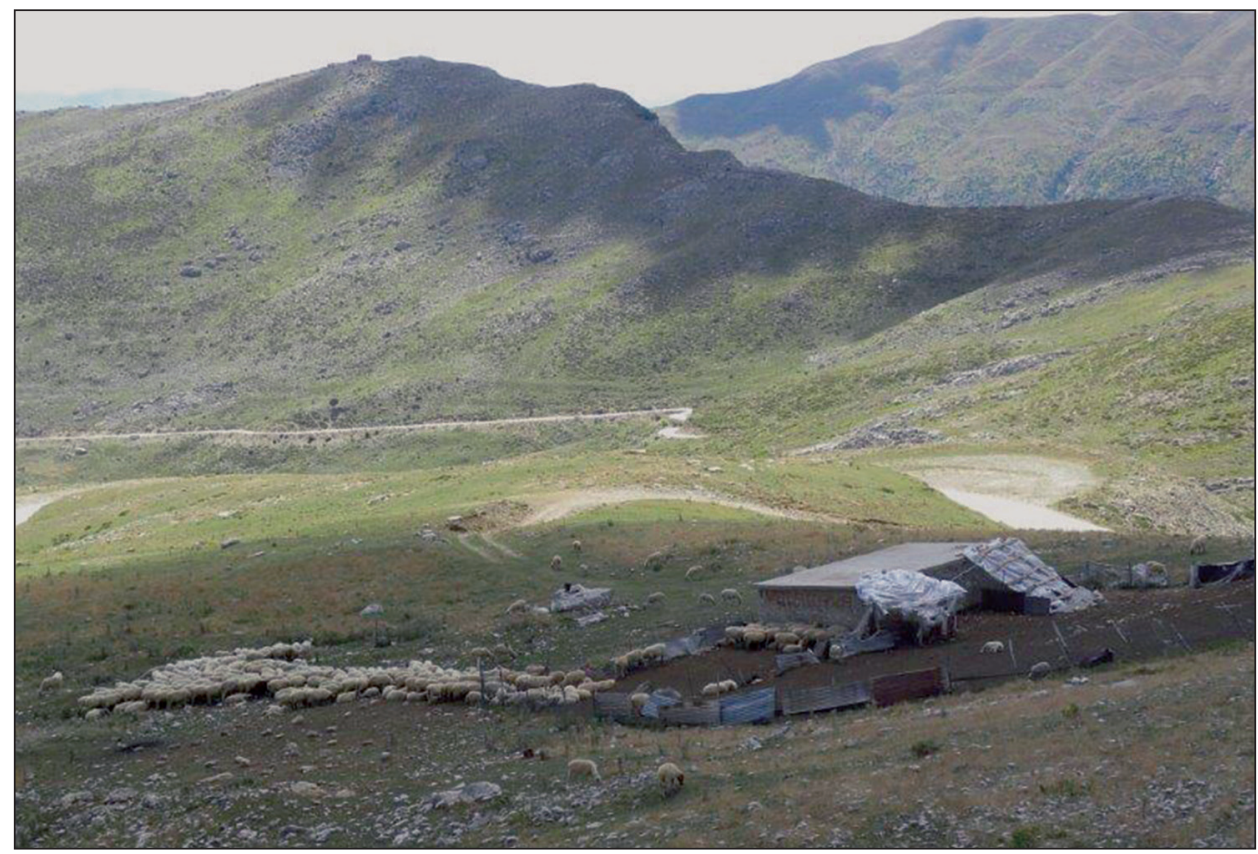

Photo 1. Epirus (Pindos Mountains), August 2015 (photo by Karolina Kocój)

${ }^{3}$ G. L. Weigand, Die Aromunen: ethnographisch-philologisch-historische Antersuchungen über das Volk der Sogenannten Makedo-Romanen oder Zinzaren, Leipzig [1894-1995 (Bd. 1, 1895)]. 
The search for the Aromanian cultural heritage also covers the southwestern part of today's Republic of Macedonia, which, after the upheavals of the late $18^{\text {th }}$ and $19^{\text {th }}$ centuries and the first half of the $20^{\text {th }}$ century, became a shelter for Aromanians migrating from today's Albania. Parts of these territories were probably also the original locations of Aromanian settlement. Traces of this population's cultural heritage have been discovered predominantly in certain villages of the Pelister Mountains, as well as in the vicinity of Lake Ohrid and Lake Prespa, and more specifically in the villages near Struga (Upper Belica and Lower Belica) and near the cities of Bitola (referred to as the new, second Voskopojë in the mythical $19^{\text {th }}$ century explications) and Kruševo (called the third Voskopojë) ${ }^{4}$.

I define the above areas as the $\mathrm{or}$ i g i $\mathrm{n}$ a $\mathrm{l} \mathrm{te} \mathrm{r} \mathrm{r}$ i t o r i e s of the Aromanian population, because even though researchers from different countries put forward a myriad of diverse hypotheses about the origin of Aromanians, the vast majority of them is willing to admit that the oldest traces of this culture come from the aforementioned areas of today's Greece, Albania, and the FYROM'.

\section{THE TANGIBLE CULTURAL HERITAGE OF AROMANIANS}

The research carried out in the Aromanian areas shows that despite the difficult history of this ethnic group, there are numerous well-preserved traces of its settlement and tangible cultural heritage. Due to different political animosities affecting this region since the $18^{\text {th }}$ century, a series of wars and conflicts between ethnic and religious groups that lived or live in the Balkans, civil wars, and the particularly severe communism and atheism after World War II, many Aromanian cultural artifacts are in a damaged condition. Fortunately, some small part of this heritage has undergone restoration thanks to the mission of "guarding the patrimony" by those living in places where the Aromanian roots lie, the nostalgia of those who had to leave these territories, but have never forgotten about their homeland, and the revitalization activities undertaken by various European NGOs since the turn of the $20^{\text {th }}$ and $21^{\text {st }}$ centuries. The remaining portion of the Aromanian legacy was not that lucky and is in a catastrophic

${ }^{4}$ T. Taminden, The Vlach in the Republic of Macedonia. A Success Story or a Minority on Road to Extinction?, in: The Forgotten Minorities in of Eastern Europe - the History and Today of Selected Ethnic Groups in Five Countries, ed. A. Tanner, Helsinki 2004, pp. 201-240.

${ }^{5} \mathrm{H}$. Abadzi, The Vlachs of Greece and their Misunderstood History, https://www.academia.edu/3804965/The_Vlachs_of_Greece_and_their_Misunderstood_History_English [accessed on: 24 November 2015]; M. Ruzica, The Balkan Vlachs/Aromanians Awakening, National Policies, Assimilation, http://cincari.org/dokumenta/free/The_Balkan_Vlachs-Aromanians.pdf [accessed on: 26 November 2015]. 
state - artifacts are destroyed and part of the buildings is in a decrepit condition. The monuments reduced to fragments by wars and conflicts provide a lot of leeway for revitalization enthusiasts and professionals to get creative in their reproduction of individual sites based on familiar examples from other regions. It is not always clear to whom the Aromanian artifacts belong. Some of them are included on the list of historical monuments of particular countries (Albania, Greece, Macedonia) and therefore they are treated as a national treasure (which often ends with just that, nothing more); part is in the custody of autocephalous Orthodox churches (which, just like the state, carry out their custodian duties in different ways) or local Aromanians (who try to renovate the sites as well as they can); yet another part includes abandoned villages with the ruins of stone houses and churches which fall under the category of "heritage without heirs", which significantly impedes revitalization activities. At the same time, this is a battlefield of potential conflicts, because wherever there are attempts at revitalization, there is also commercialization, which divides people and brings negative effects to local communities.

\subsection{ORIGINAL SITES}

I have initially divided the Aromanian tangible cultural heritage into two categories ${ }^{6}$. The first one encompasses tangible sites, which I call original, founded by the members of this ethnos or directly for it. These are mainly Orthodox churches and Orthodox monasteries, small religious architecture, religious artifacts and objects, as well as preserved fragments of old trade routes, stone bridges, and original residential and farming buildings.

Contemporary Aromanian reports on the oldest monuments, which concern the areas located in central and southern Albania, date back to the $15^{\text {th }}-17^{\text {th }}$ centuries; however, there is still a shortage of historical documents that could corroborate these foundations. A larger number of monuments come from the turn of the $17^{\text {th }}$ and $18^{\text {th }}$ centuries when the Aromanian culture was in its heyday associated with numerous economic and religious privileges received from the Ottoman rulers. Some of the oldest Aromanian artifacts include buildings located in the vicinity of Korçë, e.g. in the village of Shipskë, which is home to the $17^{\text {th }}$ century three-aisled stone Orthodox church of St. George (Albanian: Kisha e Shën Gjergjit), surro-

${ }^{6}$ For the sake of factual clarity, this section is limited to only selected towns/villages and monuments from the areas of Albania, Greece and Macedonia. The classification of the heritage with descriptions of other sites is the subject of another study. 
unded by arcades and with fragments of exterior polychrome (foundation fresco) above the portal. The interior of the church is covered with polychrome depicting saints, warrior knights, Mother of God surrounded by prophets and angelic choirs (the dome), and the monumental composition illustrating the Dormition of the Mother of God. Inside the church, there is a wooden iconostasis topped with a cross, with icons painted on wood - the artifact important for the study on the tangible heritage of Vlachs.

At this time, probably in the $18^{\text {th }}$ century, Aromanians built their churches also in the village of Grabova (Aromanian: Greãva) in the county of Gramsh, origins of which, according to contemporary Aromanian narratives, date back to the $10^{\text {th }}$ century. They were most probably founded on the site of old religious objects. These are: (1) the Orthodox Church of St. Paraskeva (Aromanian: Stâvinere), dated to 1718, with well-preserved interior polychrome frescoes depicting numerous figures, including St. Paraskeva, and with fragments of a wooden iconostasis and a few icons (including of St. Michael the Archangel); (2) the Orthodox Church of St. Nicholas (Aromanian: Ay Nicóla), reportedly founded in 1759, with a tower, well-preserved arcades, small apse, and frescoes depicting angel choirs, Christ Pantocrator, and holy warrior knights (St. Michael and St. Demetrius) $)^{8}$. In addition, what can also be found in Grabova are the ruins of old roads, stone bridges, and sewage system of the city and the school of Simon Baba, whose origin, however, still requires a thorough examination?.

Moreover, the same period abounds with the largest number of confirmations about Voskopojë - the now "mythical" city of Aromanians (Aromanian: Moscopole, Moscopolea), whose origins date back to the $15^{\text {th }}$ century in traditional Albanian and Vlach narratives. The preserved artifacts of the Vlach history and culture, which today are the symbols of "the invisible city", were founded in the $17^{\text {th }}$ and $18^{\text {th }}$ centuries. These include Orthodox churches, religious objects, the remains of stone buildings, as well as the remnants of the ancient trade route, which used to run through the city. One of the oldest temples is the Orthodox Church of St. Nicholas (Albanian: Kisha e Shën Kollit), founded by Hadji Georgi and built in the years 1721-1722. The church was decorated with interior polychrome by David of Selenicë in 1724 (or 1726) and by Constantine (Kostandin) and

\footnotetext{
${ }^{7}$ Balkan's Digest, directed by Ionuț Piturescu, Romania 2008.

${ }^{8}$ Fotomontazh Grabova, https://www.youtube.com/watch?v=UoCHjPZrDsg [accessed on: 10 October 2015]; Reportage Grabova, Elbasan. AST Elbasani, Alpinizem, Skidhe Turizem Malor, http://www.youtube.com/watch?v=g5uz4T-VeOg [accessed on: 10 October 2015].

${ }^{9}$ Shculia armănească Grabova, http://aromanian.tv/videogallery/shculia-armaneasca-dihoara-grabova1618479520 [accessed on: 10 October 2015].
} 


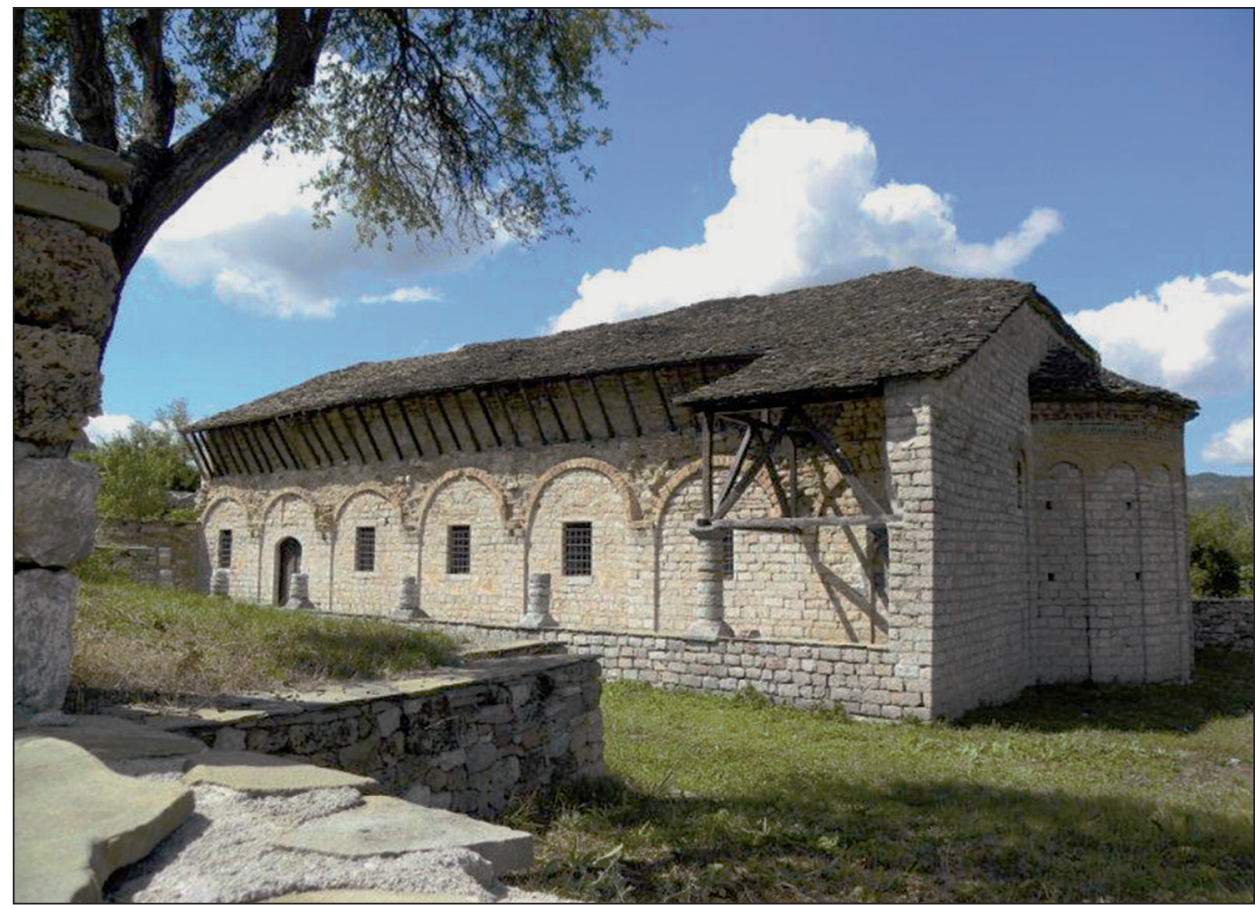

Photo 2. Orthodox Church of the Dormition of the Mother of God, $17^{\text {th }}$ century (photo by Karolina Kocój)

Athanasius (Athanas) from Korçë in $1750^{10}$. The outer walls of the church are also covered with polychrome with the distinctive representations of holy warrior knights, scenes from the life of St. Nicholas, the patron of the church, and the large-size composition of the Transfiguration and Crucifixion of Jesus ${ }^{11}$. Inside the building, one can see unspoiled icons painted in the years 1722-1726 by the renowned icon-painter Constantine Ieromonachos. In addition to this church, there are other temples in Moscopole, which are crucial in the context of the Aromanian cultural heritage

${ }^{10}$ R. Rousseva, Iconographic Characteristics of the Churches in Moschopolis and Vithkuoi (Albania), "Makedonika" 2006, 35, p. 166, http://media.ems.gr/ekdoseis/makedonika/makedonika_35/ekd_pemk_35_Russeva.pdf [accessed on: 31 October 2015]; A. Palushi, The Life Cycle of St. Nicholas Conducted in Basilica of "St. Nicholas" in Voskopoje, "Anglisticum Journal (IJLLIS)" 2013, 2, 4, pp. 312-315; Emergency Restoration St. Nicholas Church, Voskopoja, http:// albania.nlembassy.org/binaries/content/assets/postenweb/a/albanie/netherlands-embassy-in-tirana/2013/may/pcf_chwb_voskopoja.pdf [accessed on: 31 October 2015]; A. Palushi, The Life Cycle of John the Forerunner in the Basilica of St. Nicholas in Voskopoja, http://konferenca.unishk.edu.al/icrae2014/cd/pdfdoc/115.pdf [accessed on: 15 October 2015]; Kisha e Shën Kollit, http://www.imk.gov.al/?page_id=465 [accessed on: 20 October 2015].

${ }^{11}$ Field research, Moscopole, Albania, August 2015. 
research, including the basilica-type Orthodox Church of St. Athanasius (Albanian: Kisha e Shën Thanasit), raised in the years 1721-1724, covered with interior and exterior polychrome by painters Constantine and Athanasius of Korçë in 1745, with a well-preserved bell tower at the entrance to its premises. The church was built in stone on a rectangular plan; it has arcades open to the outside. Other vital sites (research-wise) include: the Orthodox Church of St. Elijah (Albanian: Kisha e Shëndëlliut), which is the only surviving fragment of the 1751 Moscopole monastery; the Orthodox Church of St. Michael and Gabriel the Archangels (Albanian: Kisha e Shën Mëhillit or Kisha Kryeengjëjt Mihail dhe Gavriil), founded in 1722 probably by Vret Bezuk; the stone monastery of St. John the Baptist (Albanian: Manastiri i Shën Prodhromit), built on a rectangular plan in 1632 and covered with polychrome in 1659; and the large Orthodox Church of the Dormition of the Mother of God (Albanian: Kisha e Shën Marisë), built between 1694-1699 and covered with interior polychrome by Theodoros Anagnosti and Sterianos of Agrapha in 1712 $2^{12}$. What is paradoxical is that the fate of the historic monuments of Moscopole is also discernible in the city's contemporary buildings - the ruins of old stone houses and churches of the Vlach community and the ancient route were used as a building material in the new residential and farm buildings of Albanians. Today, they are the symbol of the former splendor of the city, and the part that was used to demarcate the symbolic contours of ancient religious buildings is reminiscent of sacrilegious acts perpetrated by foes on these sites ${ }^{13}$. In Greece, the old "Vlach routes" associated with transhumance shepherding pass primarily via Epirus, Thessaly, and eastern Macedonia. These traces can also be found south of these areas, including in the prefecture of Aetolia-Acarnania, Preveza, and even in the Peloponnese in the region of Arcadia $^{14}$. In the main Vlach centers in the region of Epirus in northwestern Greece, the most crucial place is Metsovo (Aromanian: Aminciu), founded in the $14^{\text {th }}$ century, probably by Aromanian shepherds ${ }^{15}$. The oldest place of religious worship here is the monastery of St. Nicholas, today located in the areas of vineyards on the outskirts of the village ${ }^{16}$. Most likely built

${ }^{12}$ Voskopojë Churches, http://www.wmf.org/project/voskopoj\%C3\%AB-churches [accessed on: 31 October 2015].

${ }^{13}$ Field research, Moscopole, Albania, August 2015.

${ }^{14}$ A. Gkoltsiou, Culture and Nature: the European Heritage of Sheep Farming and Pastoral Life. Research Theme: Routes of Transhumance. Research Report for Greece, www.prismanet.gr/ canepal/en-10-research.../89 [accessed on: 10 November 2015].

${ }^{15}$ M. Novaci, Aromânii din Siracu şi Aminciu (Metsovo - Pind, Grecia). Elemente lingvistice şi etnografice, Lucrările celui de-al XV-lea Simpozion Internațional de Dialectologie, "Journal Diacronia", Cluj-Napoca 2014, p. 247.

${ }^{16}$ Field research, Metsovo, Greece, August 2015. 
in the $15^{\text {th }}$ century, it was ornamented with interior and exterior frescoes in the $17^{\text {th }}$ and $18^{\text {th }}$ centuries (now located right next to the portal) attributed to the painter named Estathios. Inside the temple, there are dozens of icons, including by the famous Cretan painter Theodore Poulakis, who lived in the $17^{\text {th }}$ century ${ }^{17}$. Meanwhile, what today is the hub of contemporary religious worship is the Aromanian Orthodox Church of St. Paraske-

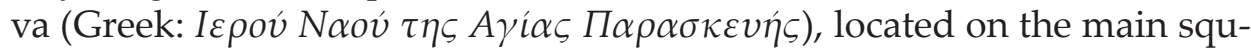
are. The information about its creation and sponsors is scarce. Built in the early $16^{\text {th }}$ century in the style of a three-aisled basilica, it was renovated several times, in 1759, 1874, 1959 and 1991. The interior polychrome is the work of Vlasios Tsotsonis and dates back to 1750-1760. It presents the scenes from the Old and New Testament as well as hagiographic representations, including the frescoes depicting St. Paraskeva ${ }^{18}$. In the context of the Aromanians' cultural heritage in Metsovo, it is also important to mention the 1754 monastery of the Dormition of the Mother of God, in the local tradition referred to as the Lower Monastery; and two other Orthodox churches: of St. Nicholas and St. Demetrius, both founded in the $18^{\text {th }}$ century.

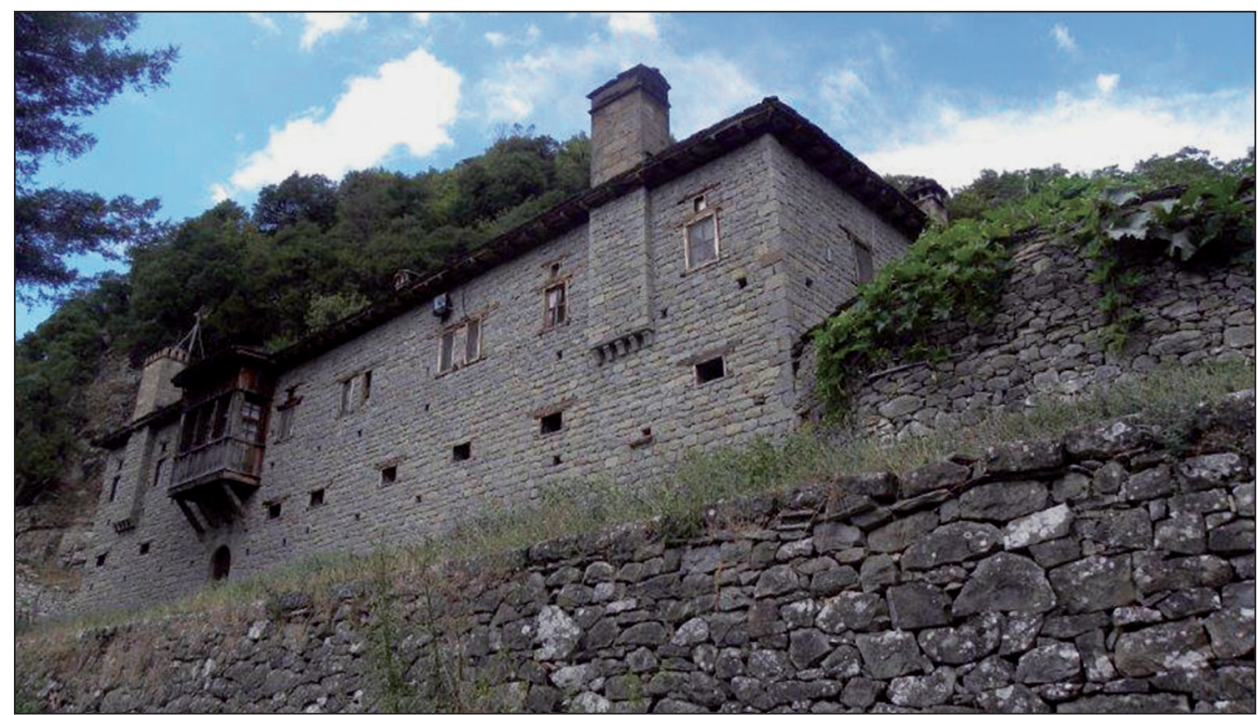

Photo 3. Monastery of St. Nicholas, Metsovo, August 2015 (photo by Karolina Kocój)

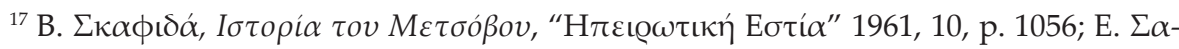

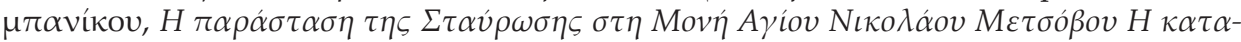

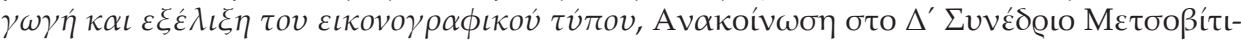

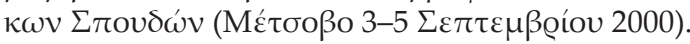

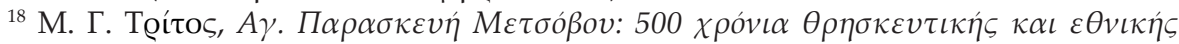

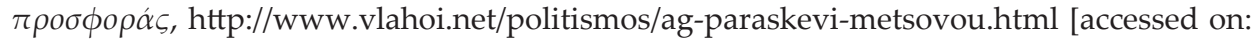
23 November 2015]. 
It is also worth paying attention to other Aromanian villages located south of Metsovo, including Syrrako (Greek: $\Sigma v \rho \rho \alpha ́ \kappa o$ or $\Sigma \iota \rho \alpha ́ \kappa o$ ) and Kalarities (Greek: $K \alpha \lambda \alpha \rho v \tau \varepsilon \zeta)$, where the representatives of this ethnic group migrated at least from the $17^{\text {th }}$ century, looking for peace in the face of growing Turkish oppression in isolated, remote places. In Syrrako, there are three stone Orthodox churches: St. Nicolas $\left(18^{\text {th }} \mathrm{c}\right.$.), Dormition of the Mother of God (Panagia, $18^{\text {th }}$ c.) and St. George $\left(18^{\text {th }}\right.$ c.). Other untouched Aromanian relics in the village include traditional stone buildings, among them houses built in a similar style (thick and large stone) and buildings with distinctive narrow stone streets stretching along the houses and ending with small squares/parking lots on the outskirts.

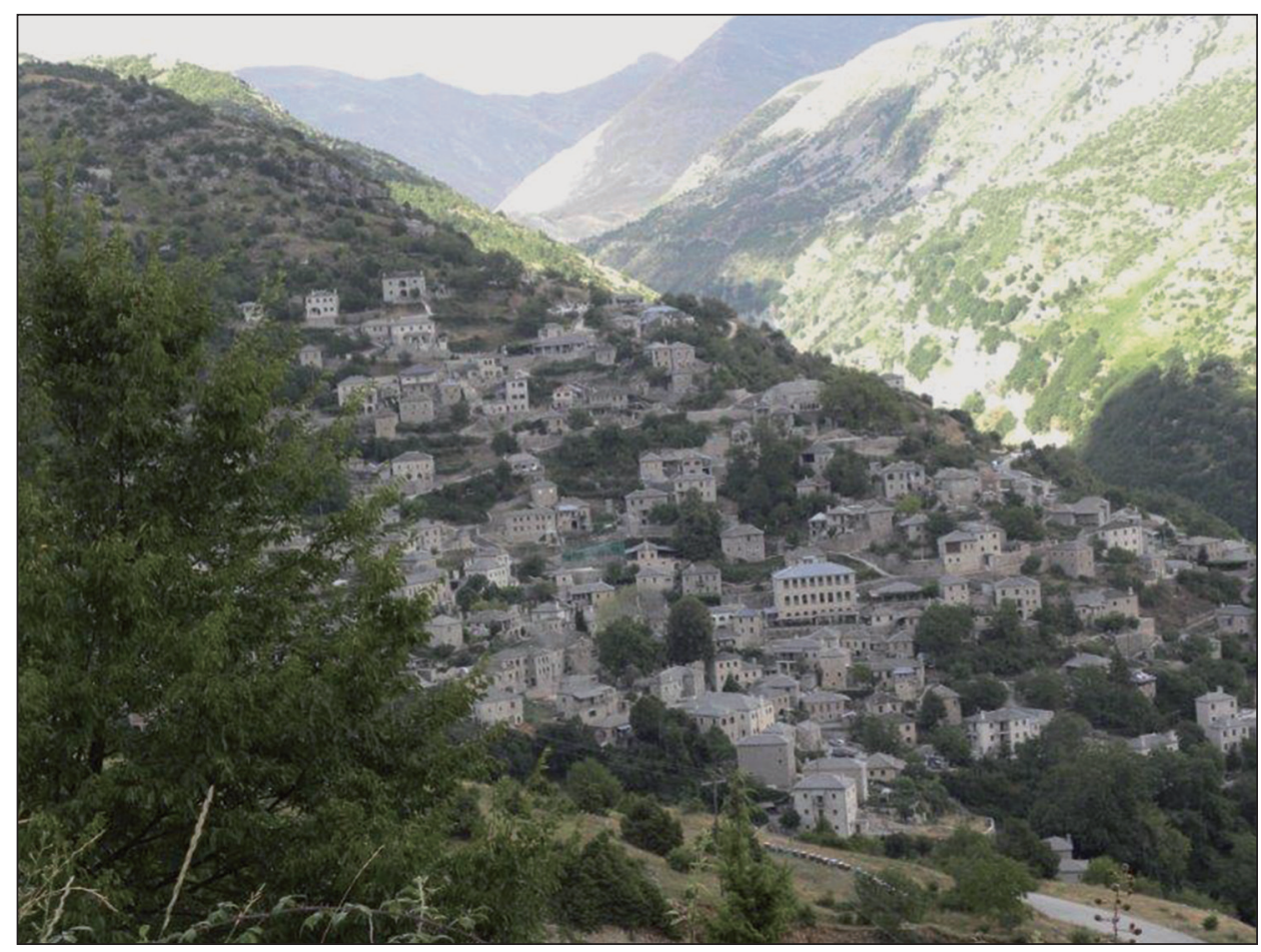

Photo 4. Syrrako village, Greece, August 2015 (photo by Karolina Kocój)

A key to Aromanian cultural heritage site in Kalarities, on the other hand, is the Orthodox Church of St. Nicolas, origins of which date back to as early as the $15^{\text {th }}$ century (probably 1480), according to certain Aromanian narratives. The church has three sections and three aisles (aisles dedicated to St. Charalambos and to All Saints). The church burned down in 1821 and was renovated 24 years later. Its interior is adorned with murals 
dated to different centuries. Another site is the Orthodox Church of the Trinity, raised in 1818, surrounded by cemeteries with the tombstones of the Aromanians, who once inhabited the village. It was destroyed during the revolution and in 1943 by German troops. In 1999 it was completely renovated thanks to the funding from the villagers. Both Kalarities and Syrrako have interesting compact stone architecture making up their traditional buildings, plus 23 bridges and 20 fountains funded by the locals. Moreover, in the village and its surroundings, there are 7 chapels, some of which are deployed on the routes of wandering cattle herds. These include: Agios Athanasios (north-west of the village), Panagia (located $1400 \mathrm{~m}$ from the village), St. Christopher (before the entrance to the village on the Ioannina-Arta side), St. Paraskeva, All Saints, the Prophet Elijah and the Transfiguration. It should also be noted that both villages have important cultural institutions, which protect the cultural heritage of Aromanians: the Museum of Kostas Krystallis, the Folklore Museum of K. Avdikos in Syrrako, and the Ethnographic Museum in Kalarities, all presenting traditional Aromanian culture and professions in these villages ${ }^{19}$.

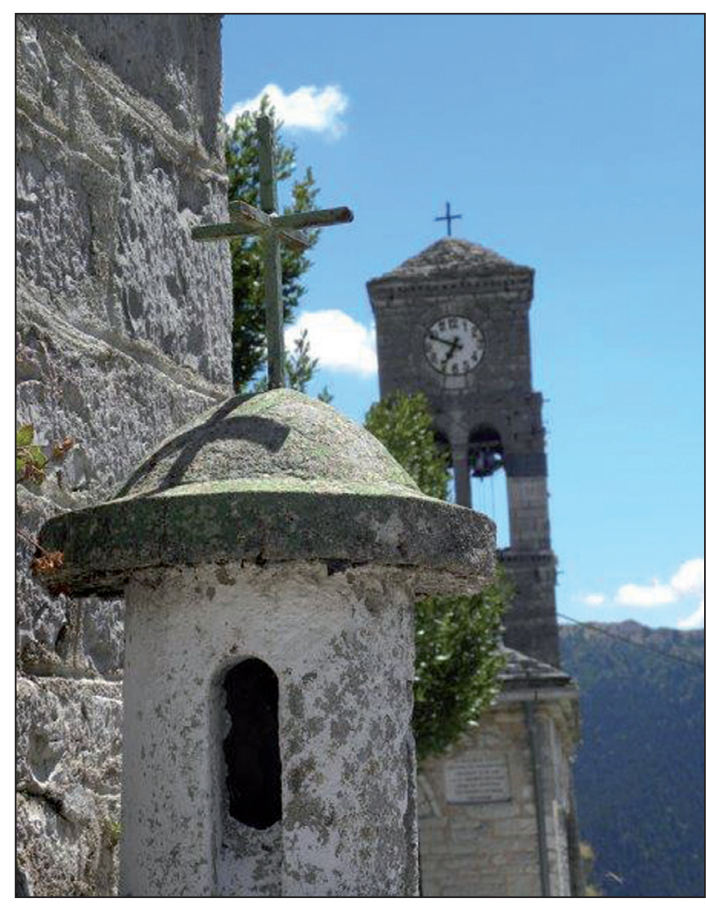

Photo 5. Kalarities, Chapel near Saint Nicholas Orthodox Church, August 2015 (photo by Karolina Kocój)

To the north of Metsovo, one should pay attention to Samarina - one of the uppermost villages in the Pindos Mountains - and the sites located therein, including: the Orthodox Church of the Transfiguration, built in 1813 and covered with interior polychrome by local masters; the Orthodox Church of St. Athanasius (1849); the Orthodox Church of St. Elijah (1795); the Orthodox Church of the Dormition of the Mother of God, also called the Great Panagia (1819); the Orthodox Church of the Nativity of the Mother of God, called the Little Panagia (1844); and the Orthodox Church of St. Kosmas (1890). Furthermore, the forests near Samarina conceal the

\footnotetext{
${ }^{19}$ Field research, Syrrako and Kalarities, Greece, August 2015.
} 
Monastery of St. Paraskeva, founded in 1713 by two monks: Nicephorus and Dionysius. In the second half of the $20^{\text {th }}$ century, Samarina received two new architectural additions: the Orthodox Church of St. Demetrios the Neomartyr (1957), under the patronage of monk Dmitri, who lived at the turn of the $18^{\text {th }}$ and $19^{\text {th }}$ centuries in Samarina and was sentenced to death during the times of Turkish domination, and the Orthodox Church of St. Michael the Archangel (1975) ${ }^{20}$.

In what is now FYROM, the Aromanian cultural heritage sites can be found for instance in Bitola and its vicinity, Struga and Kruševo. In Bitola, there is the Orthodox Church of Saints Constantine and Helen, founded by Aromanians at the beginning of the $20^{\text {th }}$ century, and the old market place called Vlaška čaršija (the Vlach bazaar), where Aromanians had their shops. In the village of Malovište, once a huge Aromanian community engaged in trade and pasturing ${ }^{21}$, there are the following testimonies of ancient history: the rock Monastery of St. Anne, located above the village at an altitude of approx. 1,400 m.a.s.l. and built probably in the $18^{\text {th }}$ century; and the stone Orthodox Church of St. Petka (Macedonian: Св. Петка; Aromanian: Hram Ay. Vinirã), a giant three-aisled basilica with a gallery on the first floor, tower, apse, and arcades, founded in 1856 on the site of the former place of religious worship. The iconostasis for this church was created in 1892, most likely by Dimitar (Dmitry) Stanishev from Kruševo. The icons were painted by artists from Kastoria (Kostura) ${ }^{22}$. The inside of the church hides over 80 icons painted on wood between the $16^{\text {th }}-19^{\text {th }}$ centuries. The site serves as the main temple of the village. Above Malovište, there is also the Aromanian Orthodox Church of the Ascension of Christ, located on the slopes of Mount Baba at an altitude of 2,000 m.a.s.l., with church services held only once a year - 40 days after Easter, on the Ascension Day. Other well-preserved sites include the traditional architecture of houses and farm buildings made of thick stone, which was also used to designate local roads and small bridges. In the $19^{\text {th }}$ century, there were about 300-700 so-called kuki (Macedonian: kyḱu) - traditional stone houses, of which only about a dozen have survived to this day ${ }^{23}$.

${ }^{20}$ Field research, Samarina, August 2015.

${ }^{21}$ Malovište (Mulovishti), http://cincari.org/vasa_prica/index.html [accessed on: 31 October 2015]; G. Kara (with Ph. Guddemi), The Spark and the New Leaf: The Aromanians of Macedonia, http://www.farsarotul.org/nl23_1.htm [accessed on: 1 December 2015].

${ }^{22}$ Field research, Malovište, FYROM, August 2013.

${ }_{23}$ М. Николоска, Маловиште архитектеонско- урбанистичкивредности, http:// www.kalamus.com.mk/pdf_spisanija/patrimonium_7/024\%20=\%20027_3\%20Patrimonium\%202014\%20Maruli\%20Nikoloska.pdf [accessed on: 10 November 2015]; М. Панов, Енциклопедија на селата во Република Македонија, Скопје 1998, р. 189. 


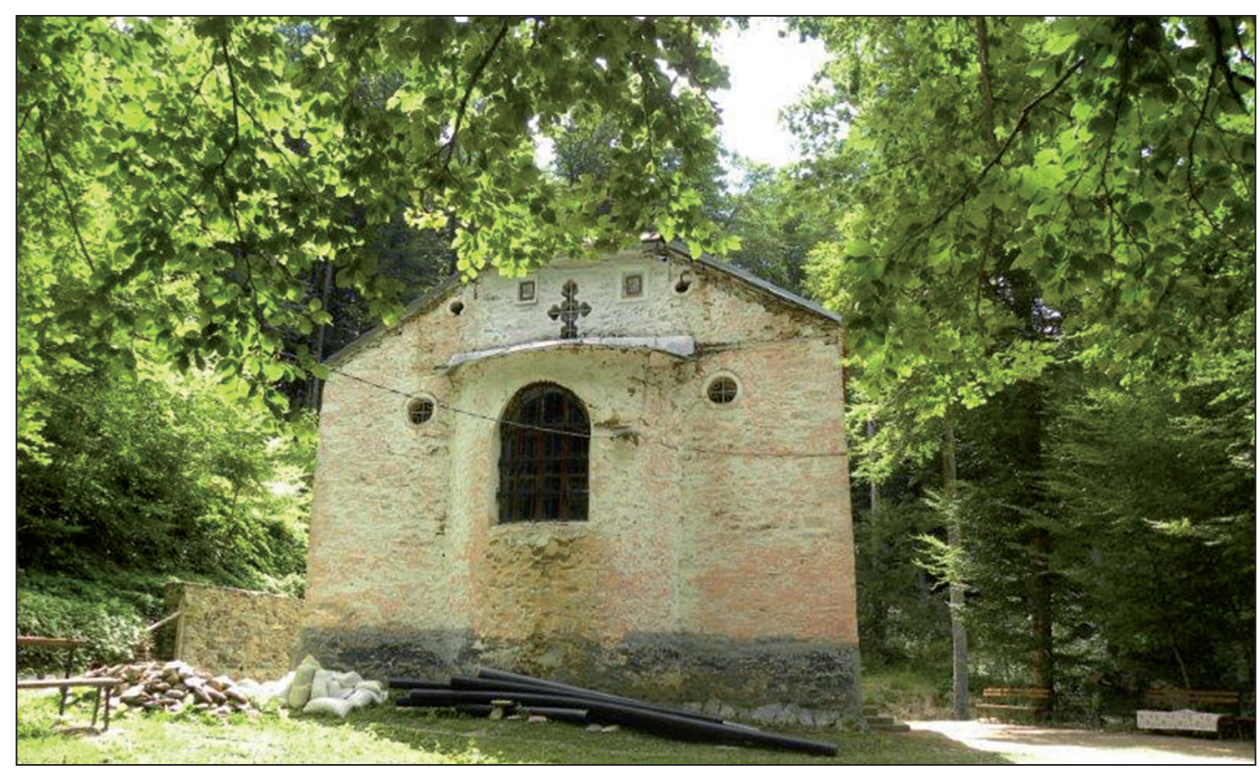

Photo 6. Monastery of St. Anne, Malovište, August 2015 (photo by Karolina Kocój)

In Gopeš (Macedonian: Tonew; Aromanian: Gopeshi), the Aromanian cultural heritage encompasses the enormous Orthodox Church of the Transfiguration (Macedonian: Преображение Господне), built in 1871, with windows and a small tower. One enters the church through a wooden portal, above which there is a mural depicting the Transfiguration, flanked on both sides with the images of the Sun and the Moon. Below the mural, there is a date of origin: 29 April 1886 (29 Aprilie 1886). On both sides of the portal, there are frescoes of the Archangels - St. Michael (left) and St. Gabriel (right), with the inscription dated to 1894. The interior of the church is equipped with an extremely large size iconostasis (the so-called high iconostasis, characteristic of the Balkans). Some rows of the iconostasis are empty; some have the icons of saints and apostles inside. In the iconostasis, there are intricately sculpted gilded tsarist gates topped with a cross, with the carvings and images of archangels and saints. The altar apse is extremely damaged; there is an altar table in the middle with a glass cabinet with a kiot (icon case) and candlesticks. By the apse walls, there extends a line of quite decrepit old icons. The interior of the apse is ornamented with frescoes.

On the walls adjacent to the portal inside the church, there are shelves with old icons. The icons are in a catastrophic condition - cracked, broken, with peeling paint. Similar monuments can also be found in: Trnovo (Macedonian: Трново; Aromanian: Tãrnuva) - the Orthodox Church of the 


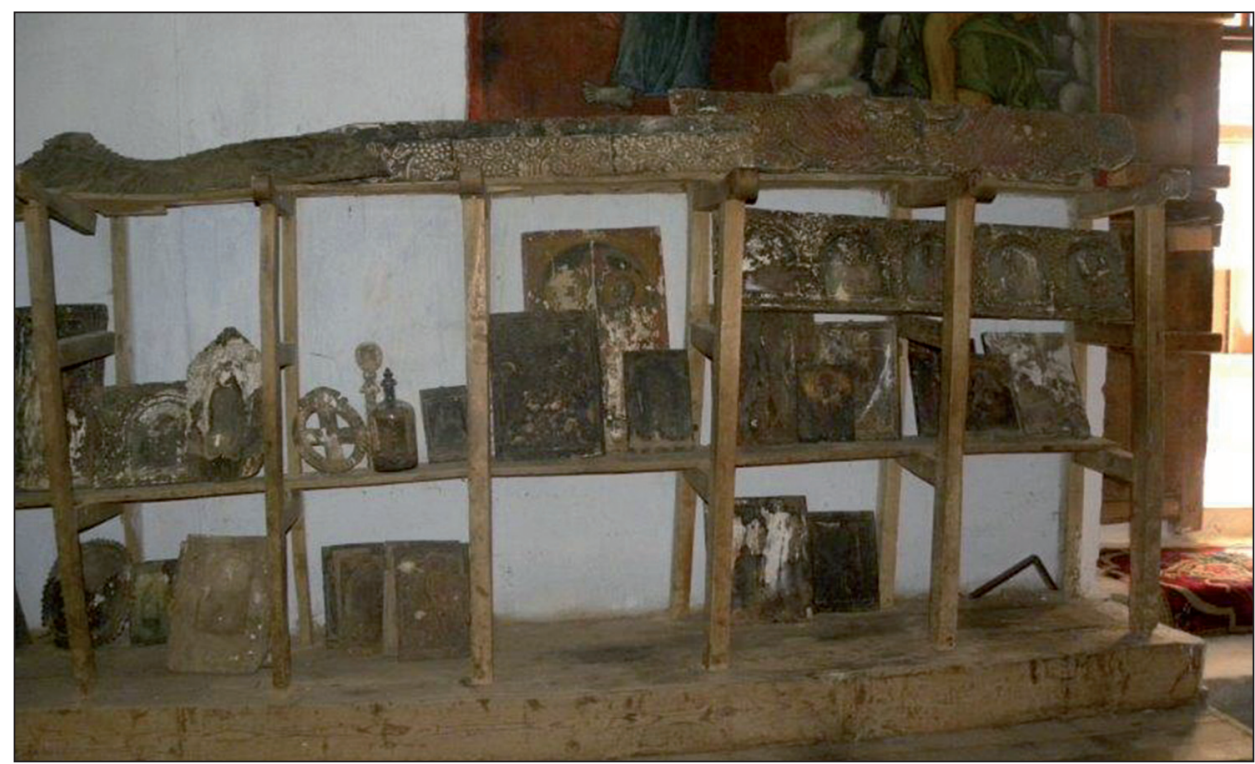

Photo 7. Orthodox Church of the Transfiguration of our Lord, Gopeš, August 2015 (photo by Karolina Kocój)

Dormition of the Mother of God, dated to 1854; Magarevo (Macedonian: Магарево) - the Orthodox Church of St. Dmitri, built in 1834; and Nižepole (Macedonian: Нижеполе; Aromanian: Nijopole) - the Orthodox Church of St. Athanasius (Macedonian: Црква Св. Атанасиј) and the Orthodox Church of St. Petka (Macedonian: Црква Св. Петка), both dated to the $19^{\text {th }}$ century. Although already from the $20^{\text {th }}$ century, very interesting sites can be admired in the north of Macedonia, i.e. Kruševo (Macedonian: Kрушево; Aromanian: Crushuva); it is the Orthodox Church of St. Nicholas (1905-1907, founded on the site of the old 1832 temple consumed by fire in the early $20^{\text {th }}$ century, with the iconostasis made by Petre Filipovski-Garkata; and the Orthodox Church of St. John, called Vlašca crkva (1897), with the iconostasis made by the masters Nestor and Lazar Alekseevsky ${ }^{24}$.

\subsection{SECONDARY SITES}

I call the second category of the Vlach cultural sites as secondary. These are monuments founded by other ethnic groups inhabiting the researched areas which, due to their religious significance and location near

${ }^{24}$ Churches and Monasteries in Macedonia, ed. T. Dimitrovski, Skopje 2012, p. 302; F. Blagaduša, Aromunojo (Walachojo) w makedonskim měsće Kruševje, "Rozklad. Serbski Kulturny Ćasopis" 2014, 12, http://www.rozhlad.de/nastawk_233.html [accessed on: 23 July 2015]. 
the Vlach routes, have become vital religious buildings for the Aromanians themselves. Sometimes, such places of worship were re-founded by Vlachs; sometimes they were completely or partially renovated and covered with interior frescoes by Aromanian artists. Among such sites, there are very old religious foundations, some of which date back to as early as the beginning of the second millennium. One of the most important landmarks here is the Orthodox Monastery of the Nativity of Our Lady (Albanian: Manastiri Lindja e Hyjlindëses Mari) located in the village of Ardeni$\mathrm{ca}$, in the municipality of Lushnje in western Albania, in close proximity to the ancient transport route called Via Egnatia. Commissioned in 1282 by the Byzantine Emperor Andronicus II Paleologus as a votive offering for the victory over the Sicilian army in the Siege of Berat, the monastery significantly deteriorated in the $17^{\text {th }}$ century. In 1743, the Archbishop of Berat - Methodius, from the Aromanian family of Farsherots, renewed the monastery; on his command, the brothers Kostandin and Athanasy Zografi of Korçë created the interior polychrome. The icon of the Madonna and

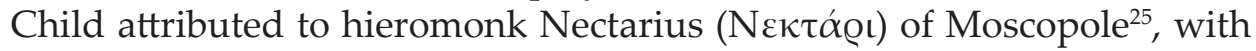
the invocation prayer in the Aromanian language, comes from this very monastery. Another heritage site of this kind is the Orthodox Monastery of Panagia Molivdokepastos, also referred to as Molivdokepasti (Greek:

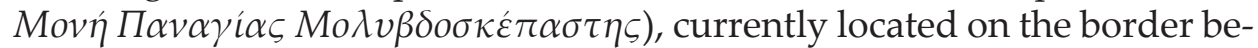
tween Albania and Greece, $20 \mathrm{~km}$ from Konitsa, with interior polychrome dating back to the $16^{\text {th }}$ century and some older fragments of exterior polychrome ${ }^{26}$. This temple is situated at the crossroads of ancient trade routes, which connect central Albania and the counties of Fier, Këlcyrë and Permet with Ioannina. There was also a different vital trade route running via Molivdokepastos, which linked Ioannina with Leskovik, Korçë and Ohrid. Contemporary monks can still remember the Vlachs grazing their herds in the surrounding areas and visiting the monastery ${ }^{27}$.

In Epirus, the Aromanian heritage is associated with the rock Mona-

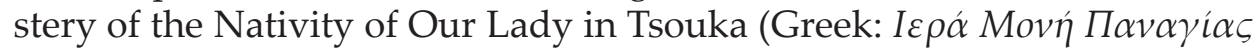

${ }^{25}$ R. Elsie, Historical Dictionary of Albania, Lanham, Maryland, and Oxford 2004, p. 22; T. Kahl, Wurde in Moschopolis auch Bulgarisch gesprochen? Überlegungen zur Slawophonie im Südalbanien des 18 Jahrhunderts, in: Probleme de filologie slavă XV, Timișoara 2007, pp. 484494; T. Kahl, E. Prifti, Geschichte der Kodifizierung des Aromunischen, Die Kodifizierung des Aromunischen, in: Zum Stand der Kodifizierung romanischer Kleinsprachen, eds. W. Dahmen et al., Tübingen 2016.

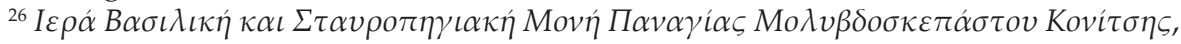

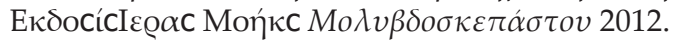

${ }^{27}$ Field research, the Orthodox Monastery of Molivdokepastos, Greece, August 2015; the interview with one of the monks from the monastery and with a Greek man from Konitsa. 


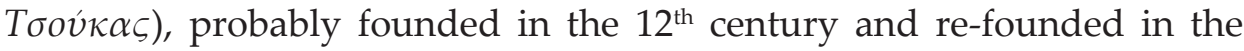
$18^{\text {th }}$ century, with rich interior polychrome dated to the $18^{\text {th }}$ century, an iconostasis, relics of St. Panteleimon and the miraculous icon of the Virgin Mary. Similar significance is given to the rock Monastery of Kipina, dedicated to the Dormition of the Mother of God, roots of which go back to 1349 .

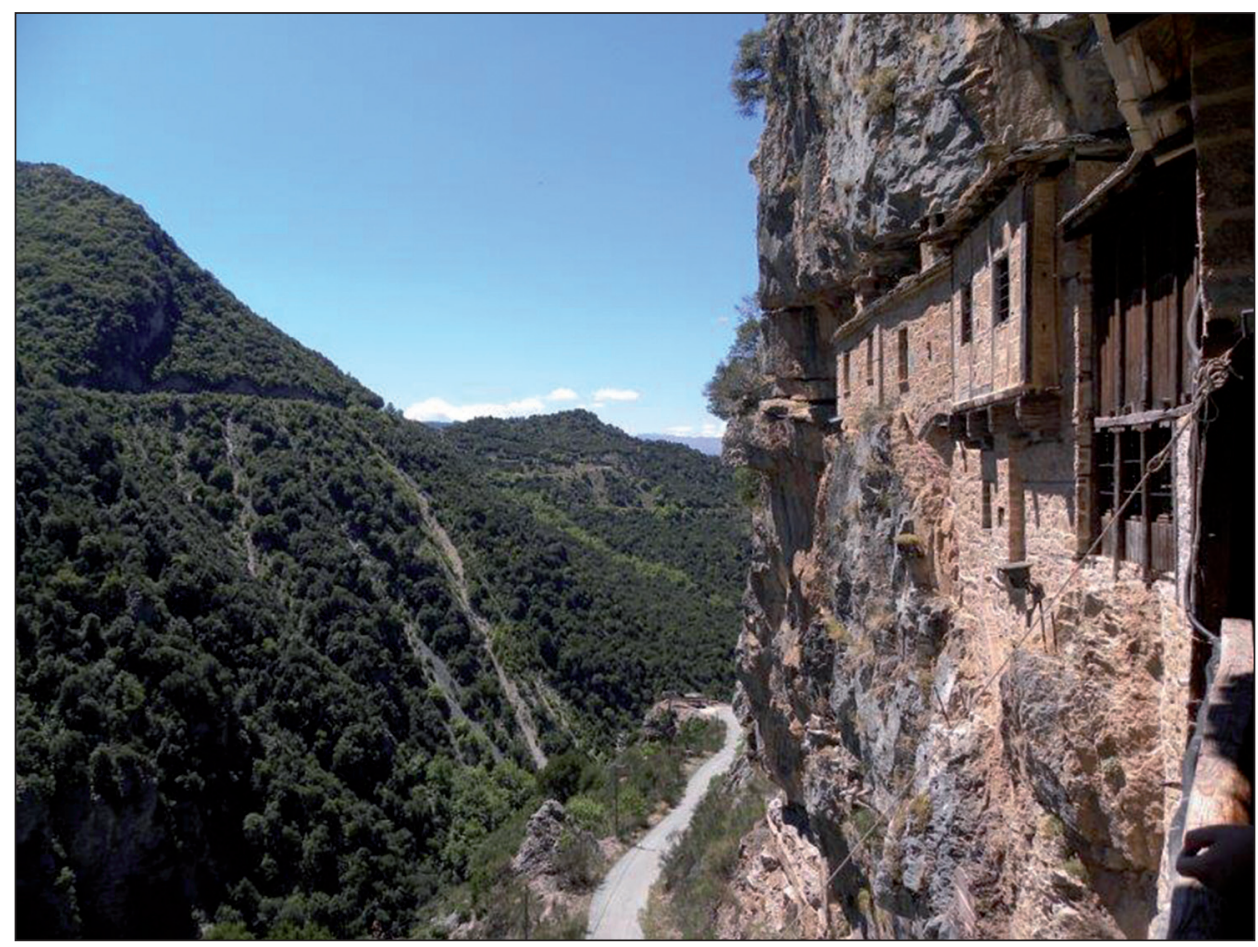

Photo 8. Monastery of Kipina (Dormition of the Mother of God), August 2015 (photo by Karolina Kocój)

The cloister lies near the village of Kalariteis. Re-founded in the $17^{\text {th }}$ century, it contains valuable interior polychrome painted in the $18^{\text {th }}$ century. The monastery was carved out of rocks. What leads to the building is a wooden moving bridge, lifted by monks at night and at the time of danger. For many Aromanians from this part of Epirus, these sites were and still are important places of worship where they come with prayers and offerings:

"We used to go to Tsouka; it's beautiful; there is a miraculous icon of the Mother of God there; it was an important place for Aromanians. And 
those from Kalarities used to visit Kipina, it's their monastery. We used to go there too; now - rarely ${ }^{28 \prime \prime}$.

In Zagori, one of the places related to the Aromanian culture (or more broadly - to pastoral culture), there is the monastery in Monodendri, situated in the Vikos Gorge. In the nearby mountains, Aromanians, but also Sarakatsani (Greek: $\Sigma \alpha \varrho \alpha \kappa \alpha \tau \sigma \alpha ́ v o l)$, used to graze their herds. Among the most important religious sites of the region, there is the Monastery of St. Paraskeva, founded in 1413-1414 thanks to the efforts of the local nobleman Michael Therianos. According to tradition, it was the nobleman's token of gratitude for healing his daughter of an incurable disease by St. Paraskeva. As time went by, the monastery became an important place of worship for the local community of shepherds, which is now almost nonexistent. The basilica, built of gray stone, consists of a small-size nave and is covered with interior polychrome painted at different times - in the $15^{\text {th }}$ century and in the late $17^{\text {th }}$ century. The building is home to numerous depictions, including the portraits of the founder Therianos, his wife, and his children ${ }^{29}$. Moreover, near Metsovo, we can visit the Monastery of Zoodochos Pigi in Anthohori, called The Red Rock (Kiatra Roşa) or The Panagia on Red Rocks in Aromanian. It was most likely founded in the $17^{\text {th }}$ century and decorated with interior polychrome in the $19^{\text {th }}$ century ${ }^{30}$.

What is a crucial religious place for many Aromanians from northern Greece and the modern-day Republic of Macedonia is the Monastery of the Nativity of Our Lady in Kleisoura, also known as Vlachoklisura (Gre-

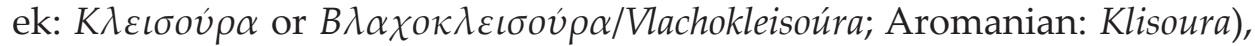
founded in 1314 by the hieromonk Neophytios and re-founded in 1813 by hieromonk Isaiah Pista from Mount Athos. This monastery was a home to "the holy mother Sofia" - a great spiritual role-model for local Aromanians $^{31}$. There is also a similar site - the Monastery of the Dormition of the Mother of God in Treskvec (Macedonian: Манастир Успение Богородица, Трескавеи), one of the most important religious centers in Macedonia, situated near Prilep, in what is now the Republic of Macedonia, founded in the $12^{\text {th }}$ century. It is worth noting that the donation documents sent to the monks of this monastery by Tsar Stefan Dušan mention, among others, the name of the donated village of Lerin (Florina), together with the Orthodox Church of St. Nicholas sold by the Vlach bishop along with the shepherds

${ }^{28}$ Field research, Sirrako, Greece, August 2015; an Aromanian woman, age 80.

${ }^{29}$ Field research, Monodendri, Greece, August 2013.

${ }^{30}$ Field research, Anthohori, Greece, August 2015.

${ }^{31}$ Eldress Sophia, the Ascetic of the Panagia, http://www.johnsanidopoulos.com/2010/06/ eldress-sophia-ascetic-of-panagia.html [accessed on: 1 November 2015]. 
and cattle ${ }^{32}$. To this day, it is a temple that plays a crucial role in the religious life of the Aromanian ethnos. Its representatives still go on pilgrimages there with their prayers and petitions addressed to Our Lady and the saints ${ }^{33}$.

\section{THE AROMANIAN TANGIBLE HERITAGE AS THE TEXT OF CULTURE}

What can we learn about the culture of Aromanians from the surviving traces of their heritage? Are the monuments preserved in whole or as ruins sufficient for us to be able to fill the void in the image of the rich and diverse world of this minority? Recognizing the traces of Aromanian cultural heritage as a specific text of culture allows researchers to read it in different contexts. Furthermore, the existence of ancient artifacts in the contemporary cultural memory of Aromanians also makes it possible to identify the anthropological clues around which reading the Vlach culture is focused.

\subsection{IDENTITY AND THE ORGANIZATION OF SPACE}

Artifacts of cultural heritage primarily bear testimony to how Aromanians created their space.

First of all, most settlements of this ethnic group are located in distinctive places - both in the vicinity of traditional trade routes and at the same time a long way from them, often hidden in the high mountains. In order to get to these places, first it is necessary to reach the remote centers of local population (Albanian, Greek and Macedonian) and then traverse a dozen or even a few dozen kilometers. Only then can one find the Aromanian enclaves, located right in the middle of nowhere (e.g. Kalarities, Syrakko, Moscopole, Gopeš, Malovište, Samarina, Grabove, etc.). Some of them are situated in strategic locations of traditional mountain trails, i.e. near or in mountain passes, which enables control over the surrounding areas (including Metsovo, Upper Belica, Nikolice). What is more, Aromanians often built their "secret" settlements in high mountains, but close to the big cities of other ethnic groups or to large commercial settlements this type of settlement was represented by Frashër near Permet, Magarevo, Nižopole, Trnovo near Bitola, Metsovo near Ioannina and Upper Plasa near Korçë. In this context, it is worth posing the question about the reli-

${ }^{32}$ S. Dragomir, Vlahii din Nordul Peninsulei Balcanice în evul mediu, Bucureşti 1959, p. 27.

${ }^{33}$ Е. Милошеска, Манастирот Трескавеи со ирквата Успение на Пресвета Богородица, in: Święta Góra Atos w kulturze Europy. Europa w kulturze Athosu, ed. M. Kuczyńska, Gniezno 2009, pp. 271-281. 
gious foundations in villages situated high in the mountains - it is known that Aromanians used to build them there because of their greater religious freedom and the lack of strong control by the Turks. Can it also indicate that by raising their sacred buildings in such isolated and inaccessible areas, Aromanians were, in fact, crypto-Christians and dual believers, which was so typical of the people inhabiting the Balkans (Islam and Christianity or Bektashism and Christianity) ${ }^{34}$. Taking into account the space organized in this way in the context of Aromanian duo theism, are we dealing with the archaic opposition top vs. bottom, where the top (as residential space) is ascribed positive values and represents the relative freedom of religion, while the bottom (as the space of work, enemy, oppressor) has negative connotations associated with slavery and forced faith?

Second of all, Aromanian settlements were linked by numerous transport routes created by this ethnos. Even today, there are well-preserved fragments of old trade routes, stone bridges spanned over mountain rivers, small roadside chapels, old wells, and man-developed water springs. Some unspoiled traces of old roads lead into the mountains towards other Aromanian settlements, bypassing or shortcutting the traditional ancient trade routes running along the main river valleys. Thus, i.e. the surviving trail emerging near the ruins of the Orthodox Church of St. Haralambos in Moscopole goes southwards to the village of Vithkuq; a similar trail runs up to the north to Shipckë and further north to the Aromanian village of Nicë. From the village of Nicolice in southern Albania leaves a trail up to the Grammos Mountains, linking their northern and southern sides. Another route was constructed via the Jablanica Mountains. It connected Elbasan with Ohrid and ran further through the once Aromanian villages of Upper and Lower Belica. This section was an alternative to traditional routes of antiquity (Via Egnatia). Furthermore, the Greek village of Metsovo was cut across not only by the ancient trail connecting Ioannina with Kalambaka, but also by the second trail leading northwards via the middle of the mountains and the villages of Vovousa and Perivoli up to Avdella and Samarina. The deep canyon separating the villages of Syrrako and Kalarities was joined by the stone bridge, and the trail ran through the mountains via another Aromanian village, Matsouki, continuing through the mo-

${ }^{34}$ S. Skendi, Crypto-Christianity in the Balkan Area under the Ottomans, "Slavic Review" 1967, 26, 2, pp. 227-246; K. Giakoumis, The Orthodox Church in Albania Under the Ottoman Rule $15^{\text {th }}-19^{\text {th }}$ Century, in: Religion und Kultur im albanisch-sprachigen Südosteuropa, ed. A. Rathberger, Frankfurt am Main 2010, pp. 69-110; E. Kocój, Pamięć starych wieków, Kraków 2013, pp. 12-15; K. Bielenin-Lenczewska, Praktyka religijna i tożsamość macedońskich muzułmanów / Torbeszów w kontekście islamizacji na Bałkanach, Slavia Meridionalis 2011, 11, pp. 267-280. 
untain passes to Athamania and then via traditional villages to Thessaly. These routes, which sometimes were incredibly steep and difficult to discover and in many cases known only to Vlachs themselves, enabled the movement of people and livestock via safer routes controlled by Aromanians. By making a fortune on transporting their goods and protecting the stock of others merchants, Vlachs slowly expanded their businesses to cover more and more new territories stretching from the western edges of southern Europe to eastern European peripheries, as well as to Russia and the Euro-Asian borderlands, and to Egypt and Africa in the south.

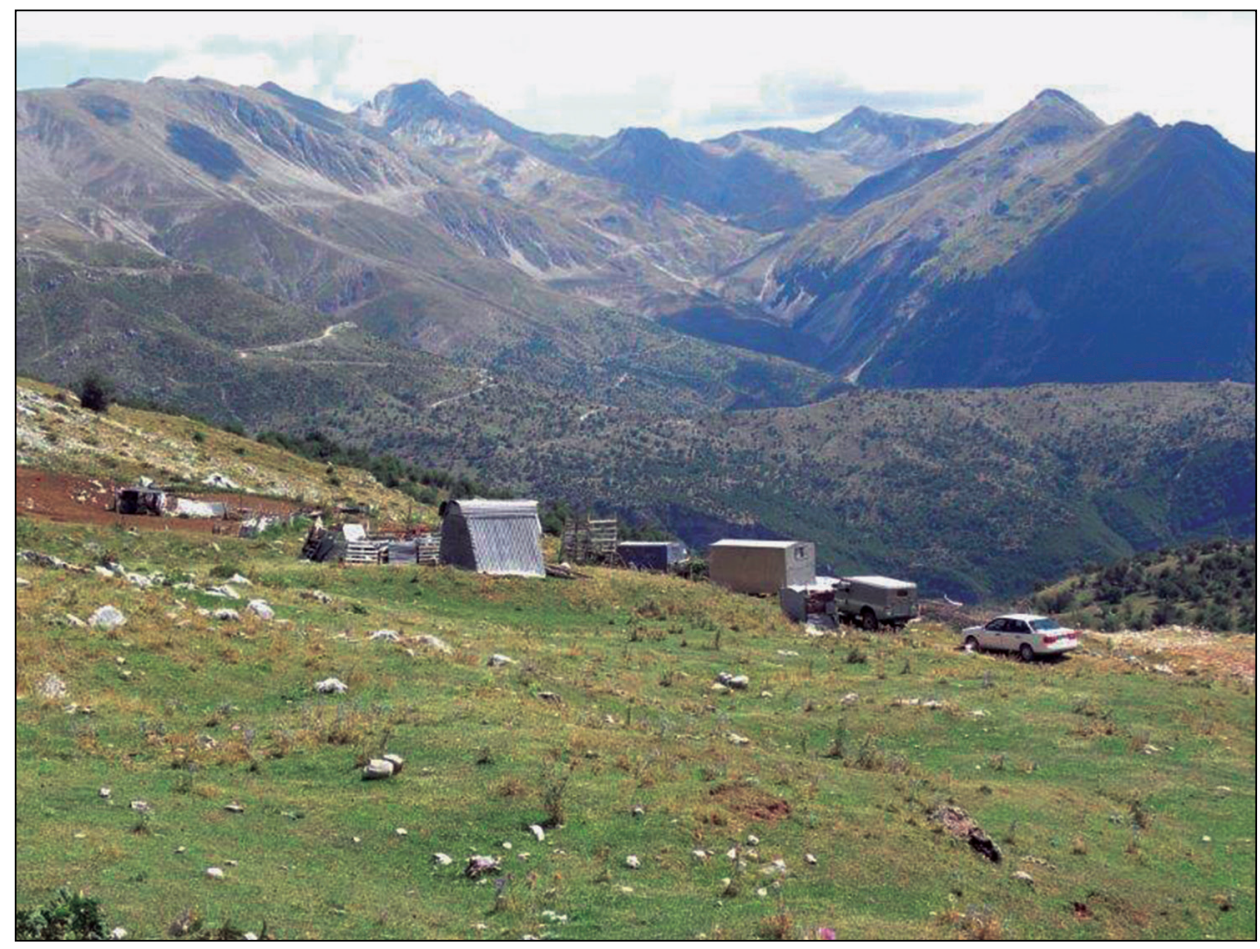

Photo 9. Pinos Mountains, August 2015 (photo by Karolina Kocój)

Thirdly, it is not difficult to notice that - especially in Greece - Aromanian villages were also lined along the likely transhumance routes (including former Aromanian villages extending from Metsovo to Kalambaka or from Athamania to Thessaly). At this point, it should be emphasized that Aromanians preferred the so-called reverse transhumance, associated with the seasonal grazing of sheep and cattle, which contributed to the unique space in which the artifacts of cultural heritage can be found. Reverse transhumance meant that mountain settlements (not valleys) were 
the main place of residence, near which Aromanians grazed their herds in summer. On the other hand, for the period of winter grazing, Aromanians migrated to warmer and lower-lying areas situated near the sea (including Muzachia in Albania, Thessaly in Greece or western Macedonia). For this reason, a significant portion of the ancient sites of Aromanian tangible culture is located up high in the mountains. Meanwhile, in the areas of winter pastures, there are secondary settlements where the Aromanian ethnos became partially or completely assimilated with the majority communities. In such territories, the traces of artifacts are rather scarce and relatively new - they date back to the $20^{\text {th }}$ century (including villages near Volos, Larissa and Trikala).

Based on the preserved monuments of tangible culture, it is possible to observe certain common features shared by the villages inhabited by Vlachs. Such settlements normally had high-density housing, with a single string of closely adjacent houses and farm buildings. Because of the terrain they were frequently built on mountain slopes, which formed the ascending terraces of settlements. In the central part of the village there usually was a temple, around which stretched a plaza or square - the hub of community life. This is where the village elders gathered and where people did business. The importance of the village center, additionally underpinned by the ancient tradition, can be seen in the structure of villages still inhabited by Aromanians today. All the roads led to the "symbolic center", which is still a gathering point for local seniors (during summer months) - examples include Sirrako, Kalarities, Metsovo and Samarina. The larger the village, the greater the number of churches, which were then located on the outskirts, thereby forming several strategic religious buildings. Perhaps they were related to the clans/families, who lived in that part of the village and could be their founders, or maybe they were of defensive nature and were to serve as shelter in case of emergency. It is worth adding that outside the village borders or on the outskirts, there usually was a monastery, often being the oldest trace of settlement in the village and constituting an important place of religious worship (i.e. Moscopole, Metsovo or Samarina).

Another distinctive feature of the Vlach tangible cultural heritage in the religious and functional sphere is associated with the network of small architecture deployed on the outskirts of villages. These are usually fountains with icons, roadside crosses, and chapels - from small ones built out of different materials (wood, brick, stone or metal) to sizable ones consisting of one large space or several smaller rooms. Located on the borders where the village buildings demarcate the end of the "familiar world" and the beginning of the "alien space", this type of architecture often determi- 
nes the symbolic valuation of the space; at the same time, such objects act as symbolic boundaries securing/protecting the locals against hostile forces, so typical of establishing the "world" in the archaic mentality. Chapels of different sizes can also be found along the traveling routes of merchant and pastoral caravans, often serving as landmarks, which make up a kind of mental map of the area. They guide shepherds or merchants in the right direction and indicate resting places. Additionally, they are treated as local religious points where Aromanians carry out various rituals. Very often, small religious architecture appears along ancient and modern Aromanian routes, sacralizing the space and setting familiar frameworks within (i.e. Kalarities or Samarina).

What is more, on the outskirts of villages along grazing areas and also along trade routes, Aromanians used to raise farm buildings: shelters for caravan-leading merchants and for animals. Even today, it is still possible to find such farm buildings made out of different materials (steel, stone or bricks) along the migration routes of the last Aromanian herdsmen - including in the vicinity of Gorica, Prespa, Rodami, Zagori, Metsovo, Sithonia, Samarina and Gramos. Their distinctive feature is that they are often placed on the site of former camps of transhumance shepherds who used to live there in past centuries in tents, which they carried with them. Moreover, some of these buildings were constructed after the Aromanian settlement and served as homes for the shepherds ${ }^{35}$.

It can be concluded that this type of space organization somehow defined Aromanians' identity - they were people living in the marches, on the run and in hiding. They were distinguished by their perpetual contact with other cultures; yet, for many years, they managed to retain ethnic uniqueness owing to their professions and a very specific arrangement of their cultural space.

\subsection{REAL AND MYTHICAL SPACES}

The artifacts of Aromanian cultural heritage allow us to infer that this ethnos had their own unique Balkan centers, which strongly influenced smaller hubs that are today only symbolic spaces. The most important center was the aforementioned city of Moscopole (Albanian: Voskopojä; Aromanian: Muskopoli, Moscopole), which name literally means the City of Shepherds (Greek: vosco - shepherd, polis - city) or the Field of Shepherds (Greek: vosco - shepherd, Slavic: polje - field) and refers directly to one of the professions performed by the vast majority of Aroma-

${ }^{35}$ Dhiava, https://www.youtube.com/watch?v=RJfom155v_o [accessed on: 1 October 2015]. 


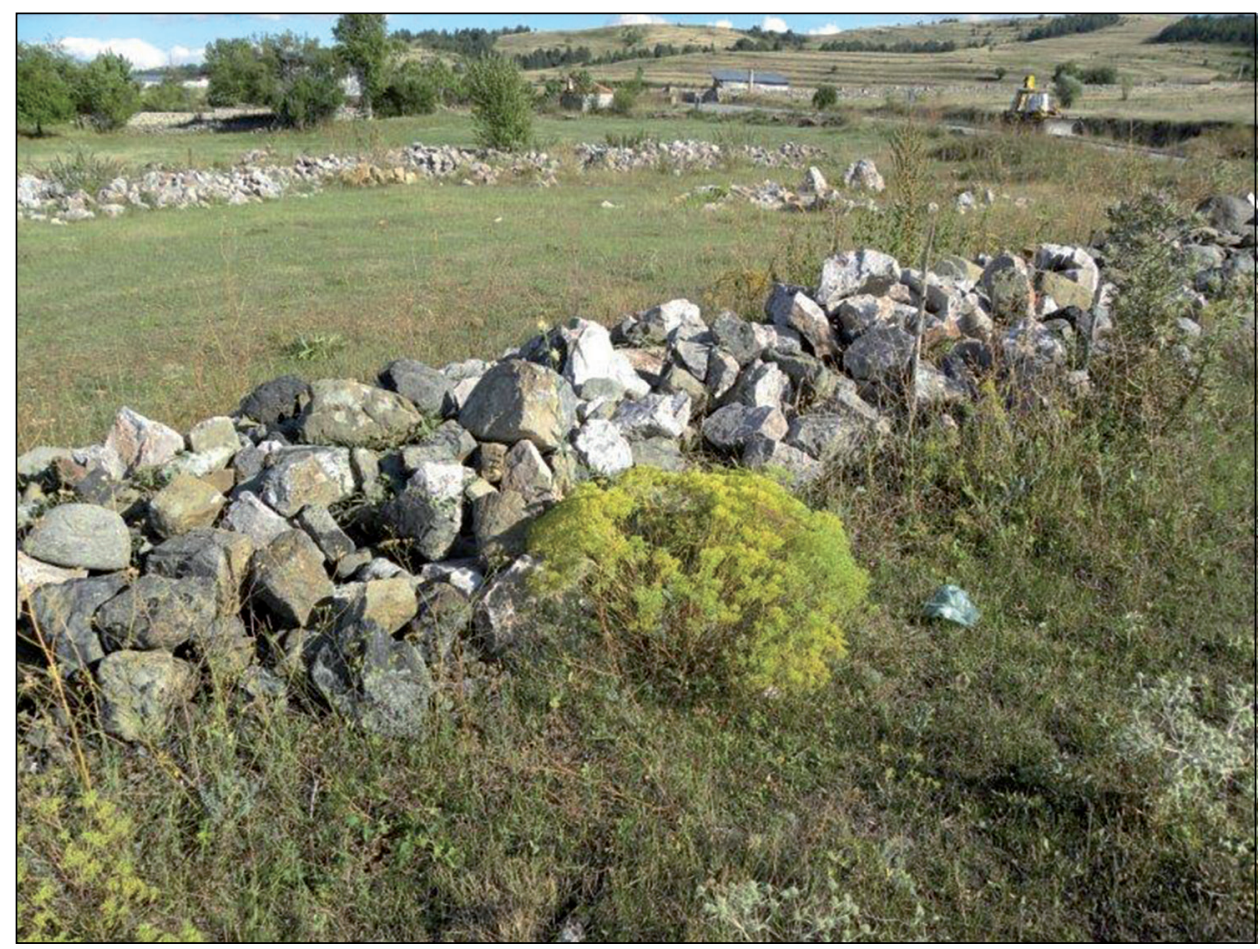

Photo 10. Epirus (Pindos Mountains), August 2015 (photo by Karolina Kocój)

nians inhabiting the region. Although it is still difficult to reconstruct a coherent history of the city, it is known that in the $18^{\text {th }}$ century it constituted a vital cultural center of the studied ethnos. At that time, the city was replete with cultural and educational institutions, including a library (established in 1710); the first Balkan printing house called the Printing House of St. Naum (est. 1720), run by a Greek native Gregorios Constantinidhi (Gregorios Typografos); and a school named the New Academy (Nea Akadimia, Hellênikon Frôntistêrion; est. 1744), with Greek as the language of instruction. It is worth adding that in the 18th century Moscopole was home to many renowned figures of religious life, among them Gregory of Durres (died 1770), also known as Gregory of Moscopole - an Orthodox monk, Bible translator and assistant rector of the New Academy, who came to Moscopole probably in 1730 and in 1741 wrote The Life of St. Nico$\mathrm{demus}^{36}$. Another great personality was the famous David Selenica - a pa-

${ }^{36}$ N. H. Ljarja, Voskopoja, One of the Most Important Hearths of Balkan Illuminist Ideas, "Journal of Educational and Social Research" 2014, 4, 3, pp. 229-232; T. Papahagi, Aromânii din Albania, Bucureşti, 1920; idem, Aromînii din punct de vedere Istoric, Cultural şi Politic, Tipo- 
inter of frescoes and icons, creator of the murals in numerous Orthodox churches in the Balkans (i.e. on Mount Athos). It is his work which contributed to the revival of certain elements of the Byzantine art of the Paleologan era in the territories of modern-day Albania ${ }^{37}$. The 1768 expulsion of Aromanians from Moscopole gave rise to the legend of the city, which in modern explications is portrayed as the Arcadia of the Balkans, a New Jerusalem or a New Athens. Today, almost each visitor to Moscopole looks for the traces of its former glory, wondering how it is possible that one of the most significant cities of the $18^{\text {th }}$ century Balkans has been reduced to several churches, some ruins and some stones, being the last vestiges of the old roads, sticking from the ground or built into the walls of new Albanian houses. The city's former prominence, as emphasized in the Aromanian narratives, is also reflected in the many multiplications of its name in the names of other cities inhabited by the expelled Aromanians: in the mythological explications Bitola is referred to as "the second Moscopole", while Kruševo - "the third Moscopole".

Another place important to the local Aromanians is the above-mentioned Metsovo (Aromanian: Aminciu) - it is mentioned in the chronicle of 1380 about the superior Isaiah and the local Vlachs, also referred to as Kutzovlachs ${ }^{38}$. The popular modern etymology of the town's name, provided by Aromanians themselves, is associated with nature: the name is probably a combination of the Slavic words mečovo meaning 'bear' and ovo meaning 'place' or 'village', where the Slavic mẹčovo might be replaced with the Aromanian term mitsio - 'bear'; in any case, the Aromanian explications report that this name is to denote 'the place of bears' or 'the village of bears' ${ }^{\prime 39}$. The dynamic development of Aromanian culture in that town was associated with many privileges received from the region's rulers (e.g. from the Byzantine Emperor Andronicus III in the $14^{\text {th }}$ century,

grafia "N. Stroilă" Bucureşti, 1915; idem, Aromânii moscopoleni şi comerțul venețian în secolele al XVII-lea şi al XVIII-lea, Bucureşti 1935; M. D. Peyfuss, Die Druckerei von Moschopolis, 17311769. Buchdruck und Heiligenverehrung im Erzbistum Achrida, Wien-Köln 1989 (= Wiener Archiv f. Geschichte eds. Slawentums u. Osteuropas. 13); E. Nowicka, Pasterze w mieście. Rola miasta w konstrukcji tożsamości bałkańskich Arumunów, in: Metropolie mniejszości. Mniejszość $w$ metropoliach, red. B. Jałowiecki, E. A. Sekuła, Warszawa 2011.

${ }^{37}$ A. Palushi, David Selenica of Vlora and his Painting in the Holy Church of Kukuzeli in the Holy Mountain (1715), The $1^{\text {st }}$ International Conference on Research and Education - Challenges Toward the Future (ICRAE 2013), 24-25 May 2013, http://konferenca.unishk.edu.al/ icrae2013/icraecd2013/doc/31.pdf [accessed on: 15 October 2015].

${ }^{38}$ A. J. B. Wace, The Nomads of the Balkans, an Account of Life and Customs Among the Vlachs of Northern Pindus, London 2013, pp. 184-185.

${ }^{39}$ Field research, Metsovo, Greece, August 2015. 
Sultan Murad II in the $15^{\text {th }}$ century and Mehmed IV in the $17^{\text {th }}$ century). These privileges guaranteed the residents of Metsovo and the adjacent villages tax deductions, relative freedom, and also administrative and religious autonomy. They were in exchange for the fact that Aromanians used to help Turks control the Libra and Katara Passes and, more specifically, their vital communication routes between Epirus, Thessaly and western Macedonia. Metsovo became a resting place for caravans, thus gaining increasingly more importance. In the $18^{\text {th }}$ and $19^{\text {th }}$ centuries it had numerous schools, slaughterhouses, shops and craftsman's workshops engaged in such businesses as i.e. woodcarving, weaving, silver processing or dairy product processing ${ }^{40}$. Despite the ravages of the 1854 Epirus Revolt, the continuity of local settlement was never interrupted - in the second half of the $19^{\text {th }}$ century the town was partially rebuilt thanks to the many funds of wealthy Aromanians from Ioannina and other Greek towns. Similarly, the new $20^{\text {th }}$ century funds of the Averroff and Totissi families have turned Metsovo into a symbol of the still ongoing prosperity of this ethnos. A visit to today's Metsovo provides (in a sometimes bitter! nutshell) a taste of everything that makes up the Aromanian history and transformation in line with the new trends of Aromanian culture - old and very valuable monuments rub shoulders with modern museums; traditional cheeses are manufactured by shepherds next to factory cheeses, which took over the former production technologies; traditional home-made wines can be found next to the mass-produced ones; and the old kilim rugs, once ornaments in traditional houses, are replaced by the new ones made for tourists with the same technique because they sell better. "The old and the new" of Metsovo can also be seen in the present-day architecture, where traditional houses are intertwined with new inns and hotels ${ }^{41}$.

In the $18^{\text {th }}$ century, another crucial Aromanian location was Gramostea/Gramousta (now Gramost), situated in the high mountains of Grammos on the border of the present-day Albania and Greece and, as the Aromanian tradition has it, surrounded by 18 hills. According to the Aromanian accounts, the fate of Moscopole is repeated once again - the town's population was about 40 thousand inhabitants, mostly Orthodox founders of numerous churches ${ }^{42}$. Although shepherding was the main profession

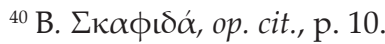

${ }^{41}$ Field research, Metsovo, Greece, August 2015.

${ }^{42}$ T. Capidan, Români nomazi. Studiu din viața Românilor din sudul Peninsulei Balcanice,

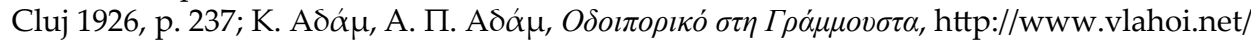
vlahoxoria/odoiporiko-sti-grammousta.html [accessed on: 5 September 2015]; A. I. Koukoudis, The Vlachs: Metropolis and Diaspora, Thessalonica 2003. 
of the Grammos Aromanians, the existence of such a large town was most probably linked with other professions, including trade. Grammos was cut across with numerous trade routes linking Albania, Greece and Macedonia for caravans with goods. According to the account of the French general Fréderic-François Guillaume (dit Guillaume de Vaudoncourt), these routes were regarded as some of the most dangerous and most difficult in the region. Their winding paths often ran through high mountain ranges known only to Aromanians. Inns were scarce, and if there were any, they were in a very poor condition - they did not offer anything more than free shelter, which was not even sufficient to protect people against bad weather ${ }^{43}$. It is already known that in the exchange for caravan protection, Turks used to give Aromanians numerous privileges, which probably contributed to the development and increased significance of Gramousta $^{44}$. Thus was emerging a new powerful enclave of the studied ethnos, which could suddenly threaten the local forces. After the destruction perpetrated by the forces sent by Turks in the $18^{\text {th }}$ century and after the Greek Civil War, in 1943-1949 the banished inhabitants of Gramousta and other localities of this mountain range moved to the areas of the Pindos Mountains, Bulgaria, Wallachia and Moldavia ${ }^{45}$, however cherishing the memory of the "times and spaces of their happiness" was.

The national identity of Aromanians began to be built around the above-described symbolic towns in line with the contemporary trends already in the $19^{\text {th }}$ and then $20^{\text {th }}$ century. It entailed that each Aromanian belongs to a community much larger than a family or clan and inhabiting the space much wider than that originally occupied by the local community. Currently, researchers are looking for the evidence of this notion also in the early codification of the Aromanian language by exploring the oldest written sources ${ }^{46}$. The aforementioned places are also the pillars of the spatial dimension of collective (social) memory, which could be described

${ }^{43}$ Gen. G. de Vaudoncourt, Memoirs on the Ionian Islands, Considered in a Commercial, Political and Military, Point of View; in which Their Advantages of Position are Described, as well as Their Rlations with the Greek Continent: Including the Life and Character of Ali Pacha, the Pres-

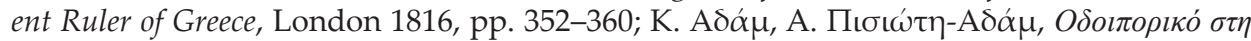
Грх́ $\mu о v \sigma \tau \alpha$, http://www.vlahoi.net/vlahoxoria/odoiporiko-sti-grammousta.html [accessed on: 5 September 2015].

${ }^{44}$ N. Bardu, Eighteenth Century Aromanian Writers: the Enlightenment and the Awakening of National and Balkan Consciousness, "Philologica Jassyensia" 2007, 3, 1, pp. 93-102.

${ }^{45} \mathrm{G}$. de Rapper, P. Sintès, Composer avec le risque: la frontière sud le l'Albanie entre politique des états et solidarités locales, "Revue d'études comparatives Est-Ouest" 2006, 37, 4, pp. 243-271.

${ }^{46}$ T. Kahl, op. cit. 
with the term mnemotopos ${ }^{47}$. Such localities are a kind of original Aromanian homeland, the ruins of which are the symbols of the perpetual migration of this minority - they are the anchor of its memory and identity.

\subsection{MULTICULTURALISM AND CONFLICT}

Traces of the Aromanian cultural heritage allow us to put forward additional conclusions, this time concerning the multiculturalism of the researched areas. The regions were inhabited not only by Aromanians, but also by Greeks, Albanians, Bulgarians, Turks, Jews and Slavs, who together formed the multicultural landscape of the Balkans. This multiculturalism led to a daily peaceful co-existence, but bred disputes and conflicts. The signs of such animosities today include the ruins, which can be seen almost anywhere in the Balkans. For Aromanians, Moscopole, which was repeatedly destroyed from the second half of the $18^{\text {th }}$ century, has again become the symbol of their eternal wandering and the outset of these conflicts. In 1769 the town fell victim to the raids of the Ottoman army and groups of Muslim Albanians - and this was because the residents of Moscopole had taken part in the preparations for the Crimean wars. In 1788, the final blow to Moscopole was struck by the forces of Ali Pasha, who burned down the buildings and expelled the residents. Despite numerous attempts, Moscopole has never regained its former glory. Rich merchants moved to Berat or to Korçë and its neighboring areas; some found new places of residence in the numerous villages of Thessaly, and even in Vienna, Budapest and the cities of Transylvania ${ }^{48}$. In the early $19^{\text {th }}$ century the town had to endure yet another destruction from Ali Pasha. Then the year 1916 brought the looting of Moscopole's cultural monuments by the Albanian gangs of the Bektashi leader Sali Butka (1857-1938) and the Austrian $\operatorname{army}^{49}$. It was then when the majority of the old Orthodox churches and their extraordinary murals, which were all the evidence of the town's former splendor, were destroyed. The final straw was the year 1943, when the remaining old-time buildings - except 4 Orthodox churches - were razed to the ground during the guerrilla war led by nationalists and fascists

${ }^{47}$ S. Kapralski, Metropolitalne przestrzenie pamięci, in: Metropolie mniejszości. Mniejszość w metropoliach, pp. 48-74.

${ }^{48}$ J. F. Trifunoski, Moskopolje - uništena hrišćanska varoš u Albaniji, Становништво словенског поријекла у Албанији, “Зборник радова са међународног научног скупа одржаног на Цетињу" 21, 22. И 23. Јуна 1990, http://dokumenta.cincari.org/free/Moskopolje_-_unistena_hriscanska_varos_u_Albaniji.pdf [accessed on: 2 October 2015].

${ }^{49}$ R. Elsie, Balli Kombëtar: The Ten-Point Programme, 1942, http://www.albanianhistory. net/texts20_2/AH1942.html [accessed on: 5 October 2015]. 
of the Balli Kombëtar organization and by Italians ${ }^{50}$. I repeat: the City of Shepherds, repeatedly destroyed and abandoned, has never regained its past glory - today it is a small village of about 1,000 residents, with the surviving traces of a wonderful past. As I have already mentioned, paradoxically, the traces of the historic monuments of Moscopole can be found in the contemporary architecture of this town, in residential and farm buildings of Albanians. To me, the most symbolic vestiges include the stones from the $18^{\text {th }}$ century Orthodox Church of St. George used to designate its former contours - which most importantly shows what a man can achieve with simple gestures in terms of restoring the memory of the place ruined by hatred and enemies ${ }^{51}$.

What has become the second symbol of conflicts and exile in recent years is Grabova (Albanian: Grabovë e Sipërme, Aromanian: Greãva) - a village situated in the Albanian mountains at 1,300 m.a.s.l., which is demanding its history to be written down. Although it has not been confirmed by sources, its establishment is traditionally dated to the $10^{\text {th }}$ century; however, the exact date of the Aromanian arrival is unknown. In their contemporary memory, the $18^{\text {th }}$ century Grabova had 2,000 families, 12,000 [?] houses and several churches. It was communicated with Moscopole via the network of roads. Plagued by gang raids since the $18^{\text {th }}$ century, it has been repeatedly abandoned by its Aromanian inhabitants, with the biggest exodus occurring in the second half of the $18^{\text {th }}$ century ${ }^{52}$.

Other contemporary symbols of conflicts and exile which affected Aromanians include the already mentioned Gramousta and the Macedonian Kruševo, both increasingly often referred to in today's mythological explications. Gramousta reminds us of the punishments, which befell its residents during the $19^{\text {th }}$ century Russo-Turkish wars and of the local civil war of the first half of the $20^{\text {th }}$ century. Some Aromanians still keep the traces of these places in their collective memory, thus building another symbolic myths. The story of the expulsion from the unique village of Gramousta recalls two events: 1 ) the year 1760, when the locality was destroyed by the Turkish troops and abandoned by Aromanians; and 2) the tumultuous events of the Greek civil war in the $20^{\text {th }}$ century, after which the few surviving inhabitants of Gramousta and other mountain villages migrated to other regions of Pindos, Bulgaria (the Rhodopes), Wallachia, Moldavia and the Danube Delta. Some of them found a new homeland in western, central, and eastern Macedonia (the lands between the rivers Me-

\footnotetext{
${ }^{50}$ R. Elsie, Balli Kombëtar: The Ten-Point Programme [accessed on: 2 October 2015].

${ }^{51}$ Field research, Moscopole, Albania, August 2015.

${ }^{52}$ N. Bardu, Among the Aromanians in Grabova (Greava), Albania. Sociolinguistic Observations, Analele Universității “Ovidius” din Constanța. Seria Filologie, XVIII, pp. 17-28.
} 
sta and Struma $)^{53}$. The second trail of their migration ran (a) to the areas of the Republic of Macedonia (near the Pelister Mountains and the towns of Bitola and Kruševo, where they mingled with the "people from Frashër" and "people from Moscopole" coming from Albania, and (b) to the northern territories of the country - near Stip and Kocani. Furthermore, Kruševo, where Aromanians came after the collapse of Moscopole and created yet another prosperous multicultural city, symbolizes the freedom, greatness and fall of the capital of the Kruševo Republic, which Aromanians managed to proclaim for a few days of 1903 together with Bulgarians, Albanians, and Greeks ${ }^{54}$.

\section{CONCLUSION}

As Gregory Ashworth wrote, the past is manifested in many forms in the present. Past is brought back by historical and ethnographic sources, recollections and tangible artifacts, but above all - by human memo$\mathrm{ry}^{55}$. In this article, the surviving traces of the cultural heritage of Aromanians have become the pretext for jogging the collective memory of Europeans about the areas of Aromanian culture which have "sunk into oblivion". The heritage becomes a process of constructing future anthropological clues and meanings, but it can also be used for negative purposes by various political and nationalist movements. The discovered tangible artifacts allow us to conclude that in the past Aromanians formed a significant community in Albania, Greece and present-day Macedonia - the community much larger than reported by all the available official statistics of the Balkan countries. Based on the preserved artifacts, the hub of Aromanian settlement can be traced back to the areas of central and south-western Albania and northwestern Greece (Epirus); the old Vlach settlements can also be found in the vicinity of Lake Prespa and Lake Ohrid. This region today hides the largest number of surviving artifacts of the said cultural heritage, including the largest number of religious, residential and farm buildings. Cultural contacts with other ethnic groups suggest that the identity of Aromanians from these areas was primarily shaped around its association with ancient Greek and Roman civilizations and also - due to the Aromanian lifestyle and professions - with the representatives of other cultures and religions. In terms of religion, the Aromanian identi-

${ }^{53}$ Calea Eschibaba (TvRadio Makedonia), https://www.youtube.com/watch?v=3f0Ois DMcj0 [accessed on: 10 October 2015].

${ }^{54}$ E. Nowicka, Nasz język rozumieja aniołowie. Arumuni we wspótczesnym świecie, Kraków 2011, pp. 229-230.

${ }^{55}$ G. Ashworth, Planowanie dziedzictwa, Kraków 2015, p. 21. 
ty could have also been determined by Eastern Christianity (the Orthodox faith), since the oldest and most numerous preserved buildings include Orthodox churches and monasteries, around which the lives of Vlachs focused. Furthermore, the oldest religious foundations of the local Vlachs, which have been discovered so far, are also Orthodox. What can be observed around the Aromanian artifacts is the existence of the world of narratives and mythical explications provided by Aromanians themselves, but also by the majority communities from the areas inhabited by the researched ethnos. On the one hand, they prove that Vlachs are building their own identity and feel nostalgic for the mythical times of happiness of the $18^{\text {th }}$ and partly $19^{\text {th }}$ century. On the other hand, the artifacts show the ideological involvement of other ethnic groups in the Aromanian heritage and their attempts to appropriate Aromanian roots (Greece, Romania).

What is more, these artifacts are the symbols of other issues, which are crucial in today's critical trends related to cultural heritage. Aromanians' cultural heritage and their contribution to the history of European culture cannot be dismissed. We can, however, pose questions about how this legacy, dug out from the past and difficult or uncomfortable for many ethnicities, will be "used" (also by Aromanians themselves) and for what purposes?

\section{BIBLIOGRAPHY}

Abadzi H., The Vlachs of Greece and Their Misunderstood History, https://www.academia. edu/3804965/The_Vlachs_of_Greece_and_their_Misunderstood_History_English [accessed on: 24 November 2015].

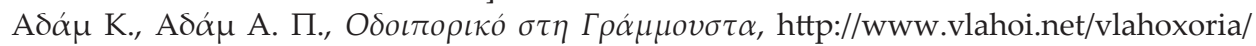
odoiporiko-sti-grammousta.html [accessed on: 5 September 2015].

Ashworth G., Planowanie dziedzictwa, Kraków 2015.

Balamaci N. S., Can the Vlachs Write Their Own History?, "Journal of Hellenic Diaspora" 1991, 17, Januar, pp. 9-36, http://pl.scribd.com/doc/46327940/Can-the-Vlachs-WriteTheir-Own-History\#scribd [accessed on: 31 October 2015].

Balamaci N. S., The Vlachs in Albania. A Travel Memoir and Oral History, http://www.farsarotul.org/nl14_1.htm [accessed on: 31 October 2015].

Bardu N., Among the Aromanians in Grabova (Greava), Albania. Sociolinguistic Observations, Analele Universității “Ovidius" din Constanța. Seria Filologie, XVIII.

Bardu N., Eighteenth Century Aromanian Writers: the Enlightenment and the Awakening of National and Balkan Consciousness "Philologica Jassyensia" 2007, 3, 1.

Blagaduša F., Aromunojo (Walachojo) w makedonskim měsće Kruševje, "Rozklad. Serbski Kulturny Časopis" 2014, 12, http://www.rozhlad.de/nastawk_233.html [accessed on: 23 July 2015].

Capidan T., Români nomazi. Studiu din viaţa Românilor din sudul Peninsulei Balcanice, Cluj 1926. 
Churches and Monasteries in Macedonia, ed. T. Dimitrovski, Skopje 2012.

Czekalski T., Perypetie historyka - o specyfice badań nad przeszłościa w krajach bałkańskich, in: Tematy trudne. Sytuacje badawcze, red. I. B. Kuźma, Łódź 2013.

Czekalski T., Zarys dziejów chrześcijaństwa albańskiego w latach 1912-1993, Kraków 1996.

Dragomir S., Vlahii din Nordul Peninsulei Balcanice în evul mediu, Bucureşti 1959.

Eldress Sophia, the Ascetic of the Panagia, http://www.johnsanidopoulos.com/2010/06/eldress-sophia-ascetic-of-panagia.html [accessed on: 13 September 2015].

Elsie R., Balli Kombëtar: The Ten-Point Programme, 1942, http://www.albanianhistory.net/texts20_2/AH1942.html [accessed on: 15 November 2015].

Elsie R., Historical Dictionary of Albania, Lanham, Maryland and Oxford 2004.

Emergency Restoration St. Nicholas Church, Voskopoja, http://albania.nlembassy.org/binaries/content/assets/postenweb/a/albanie/netherlands-embassy-in-tirana/2013/may/ pcf_chwb_voskopoja.pdf [accessed on: 31 October 2015].

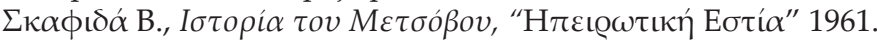

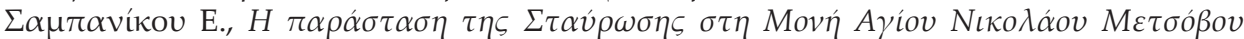

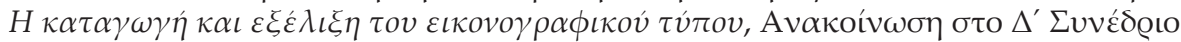

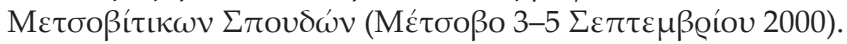

Giakoumis K., The Orthodox Church in Albania Under the Ottoman Rule $15^{\text {th }}-19^{\text {th }}$ Century in: Religion und Kultur im albanisch-sprachigen Südosteuropa, ed. A. Rathberger, Frankfurt am Main 2010.

Gkoltsiou A., Culture and Nature: the European Heritage of Sheep Farming and Pastoral Life. Research Theme: Routes of Transhumance. Research Report for Greece, www.prismanet.gr/canepal/en-10-research.../89 [accessed on: 10 November 2015].

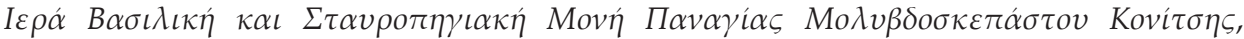

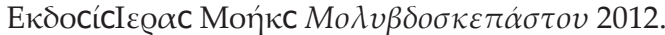

Kahl T., Wurde in Moschopolis auch Bulgarisch gesprochen? Überlegungen zur Slawophonie im Südalbanien des 18. Jahrhunderts, in: Probleme de filologie slavă XV, Timișoara 2007.

Kahl T., Prifti E., Geschichte der Kodifizierung des Aromunischen, Die Kodifizierung des Aromunischen, in: Zum Stand der Kodifizierung romanischer Kleinsprachen, eds. W. Dahmen et al., Tübingen 2016).

Kapralski S., Metropolitalne przestrzenie pamięci, in: Metropolie mniejszości. Mniejszość w metropoliach, eds. B. Jałowiecki, E. A. Sekuła, Warszawa 2011.

Kara G. (with Pf. Guddemi), The Spark and the New Leaf: The Aromanians of Macedonia, http:// www.farsarotul.org/nl23_1.htm [accessed on: 1 December 2015].

Kisha e Shën Kollit, http://www.imk.gov.al/?page_id=465 [accessed on: 20 October 2015].

Kocój E., Dziedzictwo bez dziedzica? Materialne i religijne dziedzictwo kulturowe mniejszości pochodzenia wołoskiego w Europie w kontekście projektu interdyscyplinarnych badań (przyczynek do tematu - I), "Zarządzanie w Kulturze” 2015, 2.

Kocój E., Heritage without Heirs? Tangible and Religious Cultural Heritage of the Vlachs Minority in Europe in the Context of Interdisciplinary Research Project (Contribution to the Subject), "Balcanica Posnaniensia. Acta et studia. Ius Valachicum I" 2015.

Kocój E., Pamięć starych wieków, Kraków 2013.

Koukoudis A. I., The Vlachs: Metropolis and Diaspora, Thessalonica 2003.

Ljarja N. H., Voskopoja, One of the Most Important Hearths of Balkan Illuminist Ideas, "Journal of Educational and Social Research" 2014, 4, 3.

Malovište (Mulovishti), http://cincari.org/vasa_prica/index.html [accessed on: 31 October 2015].

Maurer J., The Doubles, transl. A. Topornicka, Kielce 2002. 
Милошеска Е., Манастирот Трескавеи со ирквата Успение на Пресвета Богородица, in: Święta Góra Atos w kulturze Europy. Europa w kulturze Athosu, ed. M. Kuczyńska, Gniezno 2009.

Николоска М., Маховиште архитектеонско- урбанистичкивредности, http://www.kalamus.com.mk/pdf_spisanija/patrimonium_7/024\%20=\%20027_3\%20Patrimonium\%20 2014\%20Maruli\%20Nikoloska.pdf [accessed on: 10 November 2015].

Novaci M., Aromânii din Siracu şi Aminciu (Metsovo - Pind, Grecia). Elemente lingvistice şi etnografice, Lucrările celui de-al XV-lea Simpozion Internațional de Dialectologie, "Journal Diacronia", Cluj-Napoca 2014.

Nowicka E., Nasz język rozumieją aniołowie. Arumuni we wspótczesnym świecie, Kraków 2011.

Nowicka E., Pasterze w mieście. Rola miasta w konstrukcji tożsamości bałkańskich Arumunów, in: Metropolie mniejszości. Mniejszość w metropoliach, eds. B. Jałowiecki, E. A. Sekuła, Warszawa 2011.

Palushi A., David Selenica of Vlora and his Painting in the Holy Church of Kukuzeli in the Holy Mountain (1715), http://konferenca.unishk.edu.al/icrae2013/icraecd2013/doc/31.pdf [accessed on: 15 October 2015].

Palushi A., The Life Cycle of John the Forerunner in the Basilica of St. Nicholas in Voskopoja, http://konferenca.unishk.edu.al/icrae2014/cd/pdfdoc/115.pdf [accessed on: 15 October 2015].

Palushi A., The Life Cycle of St. Nicholas Conducted in Basilica of "St. Nicholas" in Voskopoje by Painter David Selenicas, "Anglisticum Journal (IJLLIS)", Vol. 2, Issue: 4, pp. 312-315 [accessed on: 31 October 2015].

Papahagi T., Aromânii din Albania, Bucureşti, 1920.

Papahagi T., Aromînii din punct de vedere Istoric, Cultural şi Politic, Tipografia "N. Stroilă", Bucureşti 1915.

Papahagi V., Aromânii moscopoleni şi comerțul venețian în secolele al XVII-lea şi al XVIII-lea, Bucureşti 1935.

Peyfuss M. D., Die Druckerei von Moschopolis, 1731-1769. Buchdruck und Heiligenverehrung im Erzbistum Achrida, Wien-Köln 1989 (= Wiener Archiv f. Geschichte des Slawentums u. Osteuropas. 13).

Панов М., Енцииклопедија на селата во Република Македонија, Скопје, 1998.

Praktyka religijna i tożsamość macedońskich muzułmanów / Torbeszów w kontekście islamizacji na Bałkanach, "Slavia Meridionalis" 2011, 11.

Rapper G. de, Sintès P., Composer avec le risque: la frontière sud le l'Albanie entre politique des états et solidarités locales, "Revue d'études comparatives Est-Ouest" 2006, 37, 4.

Rousseva R., Iconographic Characteristics of the Churches in Moschopolis and Vithkuoi (Albania), "Makedonika" 2006, 35.

Ruzica M., The Balkan Vlachs/Aromanians Awakening, National Policies, Assimilation, Belgrad 2006, http://cincari.org/dokumenta/free/The_Balkan_Vlachs-Aromanians.pdf [accessed on: 13 November 2015].

Skendi S., Crypto-Christianity in the Balkan Area under the Ottomans, "Slavic Review" 1967, 26, 2, pp. 227-246.

Taminden T., The Vlach in the Republic of Macedonia. A Success Story or a Minority on Road to Extinction?, in: The Forgotten Minorities in of Eastern Europe - the History and Today of Selected Ethnic Groups in Five Countries, ed. A. Tanner, Helsinki 2004.

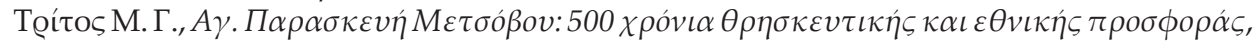
http://www.vlahoi.net/politismos/ag-paraskevi-metsovou.html [accessed on: 23 November 2015]. 
Trifunoski J. F., Moskopolje - uništena hrišćanska varoš u Albaniji, Становништво словенског поријекла у Албанији, Зборник радова са међународног научног скупа одржаног на Цетињу 21, 22. И 23. Јуна 1990, http://dokumenta.cincari.org/free/Moskopolje_-_ unistena_hriscanska_varos_u_Albaniji.pdf [accessed on: 25 November 2015].

Vaudoncourt G. de gen., Memoirs on the Ionian Islands, Considered in a Commercial, Political and Military, Point of View; in Which Their Advantages of Position are Described, as Well as Their Relations with the Greek Continent: Including the Life and Character of Ali Pacha, the Present Ruler of Greece, London 1816.

Voskopojë Churches, http://www.wmf.org/project/voskopoj\%C3\%AB-churches [accessed on: 31 October 2015].

Wace A. J. B., The Nomads of the Balkans, an Account of Life and Customs Among the Vlachs of Northern Pindus, London (original work published 1914), 2013.

Weigand G. L., Die Aromunen: ethnographisch-philologisch-historische Antersuchungen über das Volk der Sogenannten Makedo-Romanen oder Zinzaren, Leipzig [1894-1995 (Bd. 1, 1895)].

\section{Audiovisual Sources}

Balkan's Digest (2008, Romania, directed by Ionuț Piturescu).

Calea Eschibaba (TvRadio Makedonia), https://www.youtube.com/watch?v=3f0OisDMcj0 [accessed on: 10 October 2015].

Dhiava, https://www.youtube.com/watch?v=RJfom155v_o [accessed on: 1 October 2015].

Fotomontazh Grabova, https://www.youtube.com/watch?v=UoCHjPZrDsg [accessed on: 10 October 2015].

Reportage Grabova, Elbasan. AST Elbasani, Alpinizem, Ski dhe Turizem Malor, https://www. youtube.com/watch?v=g5uz4T-VeOg [accessed on: 10 October 2015].

Shculia armănească Grabova, http://aromanian.tv/videogallery/shculia-armaneasca-di-hoara-grabova1618479520 [accessed on: 10 October 2015].

\section{ABSTRACT}

The purpose of this article is to answer several questions: (1) What traces of the Aromanian (Vlach) tangible cultural heritage can be found in present-day Albania, Greece, and the Republic of Macedonia?; (2) What do such traces tell us about the local community and its history and significance in European culture?; (3) Is there today any Aromanian collective memory of the places where the traces of this heritage have been found? The article describes the regions, which used to be inhabited by Aromanians, presents the initial criteria for the division of their cultural heritage into groups by attributing selected examples of historical monuments to this ethnos and also indicates the selected meanings related to Aromanian culture, which we discover when treating these monuments as the text of culture.

I used qualitative field research methods, including photographic documentation, interviews and participant observations linked with the traces of this heritage in selected villages of Greece, Albania and Republic of Macedonia. The research also focused on the secondary (historic and ethnographic) sources as well as on resources available on the Internet-I analyzed the narratives about the relevant monuments in ethnographic sources (past and contemporary memories of Aromanians) published in the new media, including on blogs and websites. The analysis is based on the comparative historical paradigm and on the interpretative paradigm, which made it possible to study the hidden cultural meanings and codes related to the Aromanian heritage. 
The study showed that the Balkans is home to numerous Aromanian cultural heritage artifacts with which this ethnicity associates different meanings (i.e. space organization, real and symbolic places, multiculturalism and conflict).

Key words: Aromanians/Vlachs, Balkans, cultural heritage, cultural memory, symbolic places, churches and monasteries, icons, buildings, multiculturalism and conflict

\section{ABOUT AUTHOR}

Ewa Kocój - an ethnographer and cultural anthropologist who has graduated from Jagiellonian University in Krakow, Poland, and presently holds a position of an Associate Professor at Culture Institute of the Jagiellonian University. Her fields of interest include contemporary religiosity, cultural heritage, anthropological interpretation of representations and cultural symbols, as well as Eastern Christian spirituality of the Carpathian Mountains region. Prof. Kocój's research is oriented on the cultural religiosity of Romania in comparison with other Central as well as South-Eastern European countries, Eastern borderlands and national, ethnic and religious stereotypes.

The author of the following books: Sanctuaries, Persons, Icons. Painted Orthodox Churches and Monasteries of South Bukovina in Romanian Representations (2006); Romanian Saints (2012); The Memory of Old Centuries. The Symbolism of Time in the Romanian Orthodox Calendar (2013) as well as numerous academic papers published in Poland and elsewhere. She is also the editor of a scientific journal "Zarządzanie w Kulturze" ("Culture Management").

At this time she is conducting research on the contemporary Eastern Christian rituals in Europe and cultural heritage of minorities (Roma/Gypsy, Aromanians/Vlachs, Old Belivers) in Europe. 